\title{
Knowledge-Based Approach for the Structural Assessment of Monumental Buildings: Application to Case Studies
}

\author{
Silvia Caprili ${ }^{1 *}$ and Irene Puncello ${ }^{2 *}$ \\ ${ }^{1}$ Department of Civil and Industrial Engineering, University of Pisa, Pisa, Italy, ${ }^{2}$ Department of Engineering of Energy, \\ Systems, Territory and Construction, University of Pisa, Pisa, Italy
}

OPEN ACCESS

Edited by:

Michele D'amato,

University of Basilicata, Italy

Reviewed by:

Raffaele Laguardia,

Sapienza University of Rome, Italy

Giovanni Chiumiento,

University of Naples Federico II, Italy

*Correspondence:

Silvia Caprili

silvia.caprili@ing.unipi.it

Irene Puncello

irene.puncello@ing.unipi.it

Specialty section:

This article was submitted to

Earthquake Engineering,

a section of the journal

Frontiers in Built Environment

Received: 20 February 2019

Accepted: 01 April 2019

Published: 14 May 2019

Citation:

Caprili S and Puncello I (2019)

Knowledge-Based Approach for the Structural Assessment of Monumental

Buildings: Application to Case

Studies. Front. Built Environ. 5:52.

doi: 10.3389/fbuil.2019.00052
Historical buildings are characterized by a high level of complexity due to a long realization process often resulting in an overall lack of information and in a structural behavior that is more similar to a "structural aggregate" rather than to a "single building". The assessment of the static safety and seismic vulnerability then requires a multidisciplinary and multilevel approach including a deep and accurate preliminary knowledge phase before performing structural analyses. In the present paper, a consolidated knowledge-based procedure is presented and applied to four case studies in Italy. Interest is focused on the knowledge phase, combining critical-historical analysis to in situ architectural, geometrical, structural, material, and geotechnical aspects. The knowledge phase proves to be fundamental in understanding the structural behavior of cultural heritage, with special attention to the determination and analysis of local mechanisms and vulnerability elements and allowing to validate and give reason to numerical results.

Keywords: cultural heritage, historical buildings, masonry structures, multidisciplinary approach, structural assessment

\section{INTRODUCTION}

The conservation of historical-monumental buildings represents a relevant topic in Italy and in all the Mediterranean countries. Earthquake events that recently struck central regions (as an example, Umbria e Marche 1997, Puglia-Molise 2002, Abruzzo 2009, Emilia Romagna 2012, Lazio-Umbria-Marche 2016-2017) were only the last evidence of the high seismic vulnerability of the national cultural and historical heritage. During the last decades, the need of elaborating and implementing a safeguard plan was faced, aiming to protect buildings from exceptional actions and following damages and, worse, local and global failures.

Current national technical standards (D. M., 2018) deal with high accuracy the precautions and the technical prescriptions to be adopted for the seismic protection of new constructions, as function of the structural typology, of the construction site, etc. Different is the case of existing structures and, even more, the one of historical and monumental buildings, realized according to common experience, following a process of progressive optimization of structural element proportions and mainly based on functional, architectural, and practical needs, neglecting consequences in terms of structural performance, resulting loads, and effects. Structures were sized to withstand static vertical loads and static horizontal thrusts of arcs and vaults, neglecting seismic action. Seismic horizontal forces, otherwise, highly alter the funicular polygon of thrusting elements, causing diffused cracks and, in worst cases, partial collapses. Therefore, historical 
buildings are vulnerable, even if characterized by good quality materials, not always typical of constructions realized centuries ago (Lagomarsino, 2006; Castori et al., 2017). The constructive technique and the practical experience of a specific geographic area were strongly affected by the seismic hazard level and by the frequency of occurrence of earthquake events: in highseismicity areas, their relevant occurrence led to the development of constructive solutions able to reduce the seismic vulnerability. This is, for example, the case of ties and buttresses adopted in the presence of arches and vaulted surfaces, which became an integral part of constructive methodology in seismic-prone areas, being otherwise used only for retrofit or in the presence of relevant damages in other cases or after several decades from the last seismic events (Lagomarsino, 2006).

Historical masonry buildings are characterized by very complex structures, not based on a uniform constructive process and developed thanks to subsequent modifications that occurred over centuries. As a result, they behave more similar to "structural aggregates," composed by several "structural units" than to unique buildings. It is thus important to carefully study the building construction process, the presence or the lack of adequate connections among structural units and vertical and horizontal elements, the cracking scenario to identify homogeneous portions for age of construction, the defined and ongoing relative displacements of elements and components, the structural system, materials, the floor and roof typology, the geometry, and so on (Binda et al., 1999b; Formisano et al., 2010; Cattari et al., 2014; Caprili et al., 2017; Baggio et al., 2018; Castellazzi et al., 2018). Structural elementary units can be, preliminarily, analyzed as isolated buildings, further considering their interaction and mutual interrelationship accounting possible restraints conditions, basing on the structural solution adopted and in situ investigated (Oliveira, 2003; Berto et al., 2017; Degli Abbati et al., 2019) The identification of the structural units highlights the constructive discontinuities that can represent weak areas of the structural aggregate to be in deep analyzed.

In relation to what the above presented, it is evident that the deep and accurate knowledge of construction is a crucial aspect to perform valid and representative assessment of existing buildings, especially in the case of architectural and historical relevance. To neglect the complexity of their evolution, in terms of morphological processes, structural features, and typologies of bearing elements and connections among structural units leads to wrong estimations of the structural safety and, therefore, to incorrect design of retrofit measurements (Oliveira, 2003). In the last decades, several methodologies were developed to assess the seismic vulnerability of existing buildings, according to different aims and different action ranges. The selection of the most feasible analysis approach depends on many factors, for example, the need to extend results at territorial scale, building complexity, accuracy needed of the results, time required, and resource demands. Methodologies based on the macro-seismic approach at the territorial scale, using data sheets concerning structural characteristics, maintenance status, damages, and other qualitative parameters, were elaborated for fast evaluations in both post- (GNDT I level-C.N.R., 1993) and pre-event phase (DPC, 2000) (AeDES-DPC 2000), (SISMA,
2007; Zuccaro et al., 2008; Zuccaro and Cacace, 2015), or to estimate the vulnerability index on the base of relevant parameters (GNDT II level-GNDT-SSN, 1994; Bernardini and Lagomarsino 2008). Such methods allowed the analysis of a wide quantity of constructions providing a "hierarchy" useful to assess the highest/lowest need of structural assessment or retrofit interventions and the following allocation of economic resources (Bernardini and Lagomarsino, 2008).

The adoption of simplified mechanical models able to provide a vulnerability estimation based on geometrical and material parameters or on in situ survey of the cracking scenario, without resorting to complex numerical models, was also considered at the urban or single scale level. Among them, the VM method (Dolce and Moroni, 2005), RE.SIS.TO ${ }^{\circledR}$ (Mazzotti et al., 2013), or the Lv1 Method (CdM, 2011) referred to the evaluation of the collapse acceleration, accounting only for the shear resistance of masonry piers (D'Amato et al., 2018; Fuentes et al., 2019). A macro-element approach simplifying the building as an "aggregation" of a reduced number of elements with assigned behavior was adopted by D'Ayala (2002) and Augusti et al. (2001). Displacement-based approaches, aimed at defining limit states on the acceleration/displacement plane, were also provided (Cattari et al., 2004; Kržan et al., 2015; Lagomarsino and Cattari, 2015). Macro-seismic and mechanical approaches were even combined, resulting in a mixed procedure such as in the case of the VULNUS method (Bernardini, 2000): critical values of the mean acceleration response, corresponding to defined collapse mechanisms, were combined with qualitative information on buildings and soil characteristics, resulting in the assessment of the collapse probability of a single building or groups of buildings. Lagomarsino (2006) highlighted the need to adopt a multistep methodology based on an in-depth study: starting from a widescale damage analysis based on building typology and using a macro-seismic approach characterized by a fast field survey, relevant "scored" parameters were defined to modify the vulnerability index and to assess the structural performance of critical single buildings or of macro-elements/components.

Complex methodologies based on the development of highdefinition 3D numerical finite-element models were often adopted for the structural assessment of historical masonry buildings, despite the strong computational and time effort. Both linear and nonlinear analyses (Ramos and Lourenço, 2004; Chellini et al., 2014; Clementi et al., 2016; Miano et al., 2017; Ramírez et al., 2019) were used, according to the different aims and complexities. Each typology of analysis has, in fact, its own pros and cons: for example, nonlinear time-history analyses are commonly considered to better estimate the seismic demand but, at the same time, require a very strong computational effort, being not properly suited for masonry structures due to the fact that connections among elements are not easy to be represented despite their strong influence on dynamic behavior (Mallardo et al., 2008). The adoption of linear and nonlinear analyses is appealing since it allows to freely model each typology of geometry (for example, in the case of vaulted surfaces) and constitutive laws; beside, difficulties lie in the high computational effort, in the time required for modeling, and in the reliability of the model itself: geometry, construction materials, boundary 
conditions, damages, and previous repairs strongly affect the results (Roca and Elyamani, 2018), these parameters being difficult to determine. Those models need then to be "combined" with accurate geometrical survey, even by means of a laser scanner, and deep investigations on structural details, material mechanical properties, and morphological evolution of the building (Caprili et al., 2017; Formisano et al., 2017).

Regardless the chosen methodology, a proper multidisciplinary knowledge phase is essential to acquire information able to validate the results achieved. Hereinafter, a knowledge-based approach for the analysis of historicalmonumental buildings is proposed with a specific focus on the knowledge phase. To highlight the possibility of directly applying the above-mentioned approach to cultural heritage, four different case studies are presented.

\section{KNOWLEDGE-BASED METHODOLOGY}

A multilevel approach for the analysis of the seismic vulnerability of existing structures based on the accurate and reliable knowledge of the constructions themselves was proposed by Binda et al. (1999b), Binda and Saisi (2005) and applied to large-scale situations (e.g., historical city-centers), accounting for the collection of general information on different units, the execution of mechanical tests on materials, and, above all, the correlation between the in situ cracking scenario and the results of simplified macro-element analyses on relevant portions/units

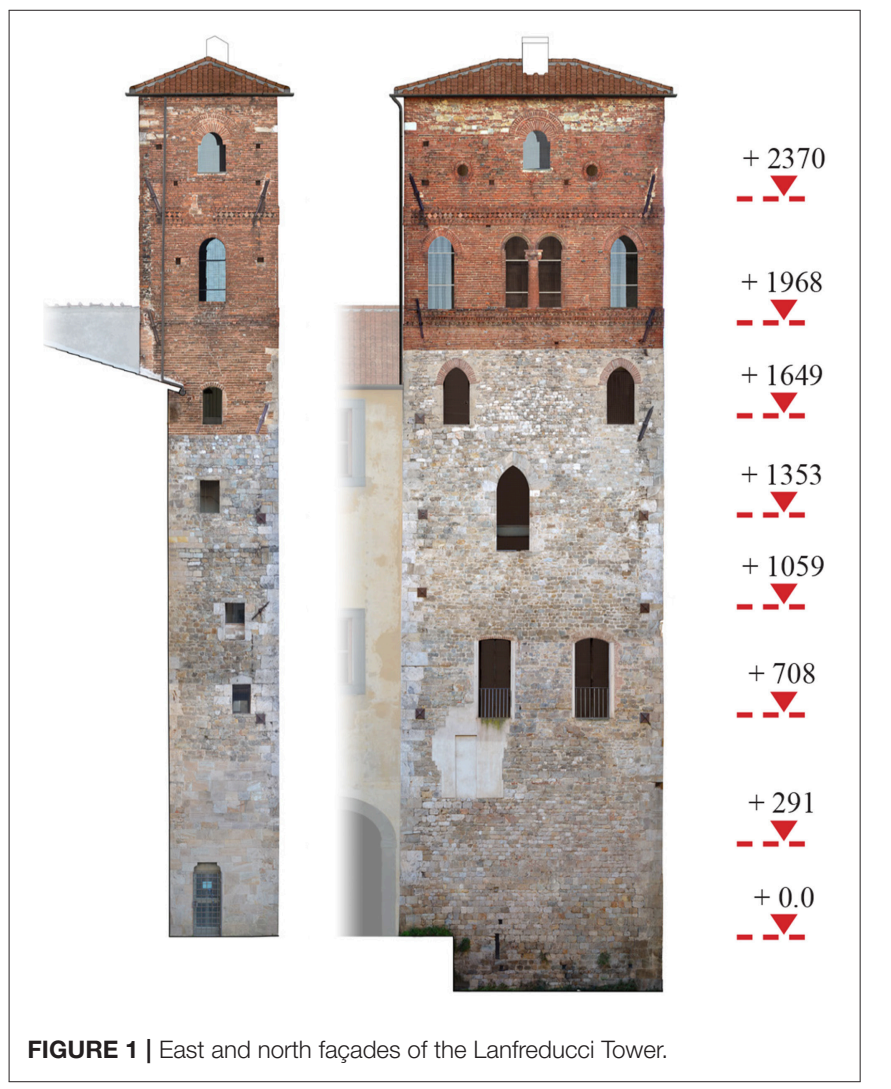

of the aggregate. Even if characterized by several analogies, in terms of structural typologies, progressive modifications due to functional needs, coexistence of different construction techniques, etc., relevant differences exist for the case of historical masonry buildings; such differences lie in their structural nature and in the architectural relevance they own. The approach shall be well specified when applied to cultural heritage, allowing to preserve and highlight their architectural, historical, and artistic value. Barbieri et al. (2013) showed the "traditional" way to assess the structural performance of a historical masonry building starting from a real case study, presenting a typical example of how to behave with cultural heritage without defining a codified approach.

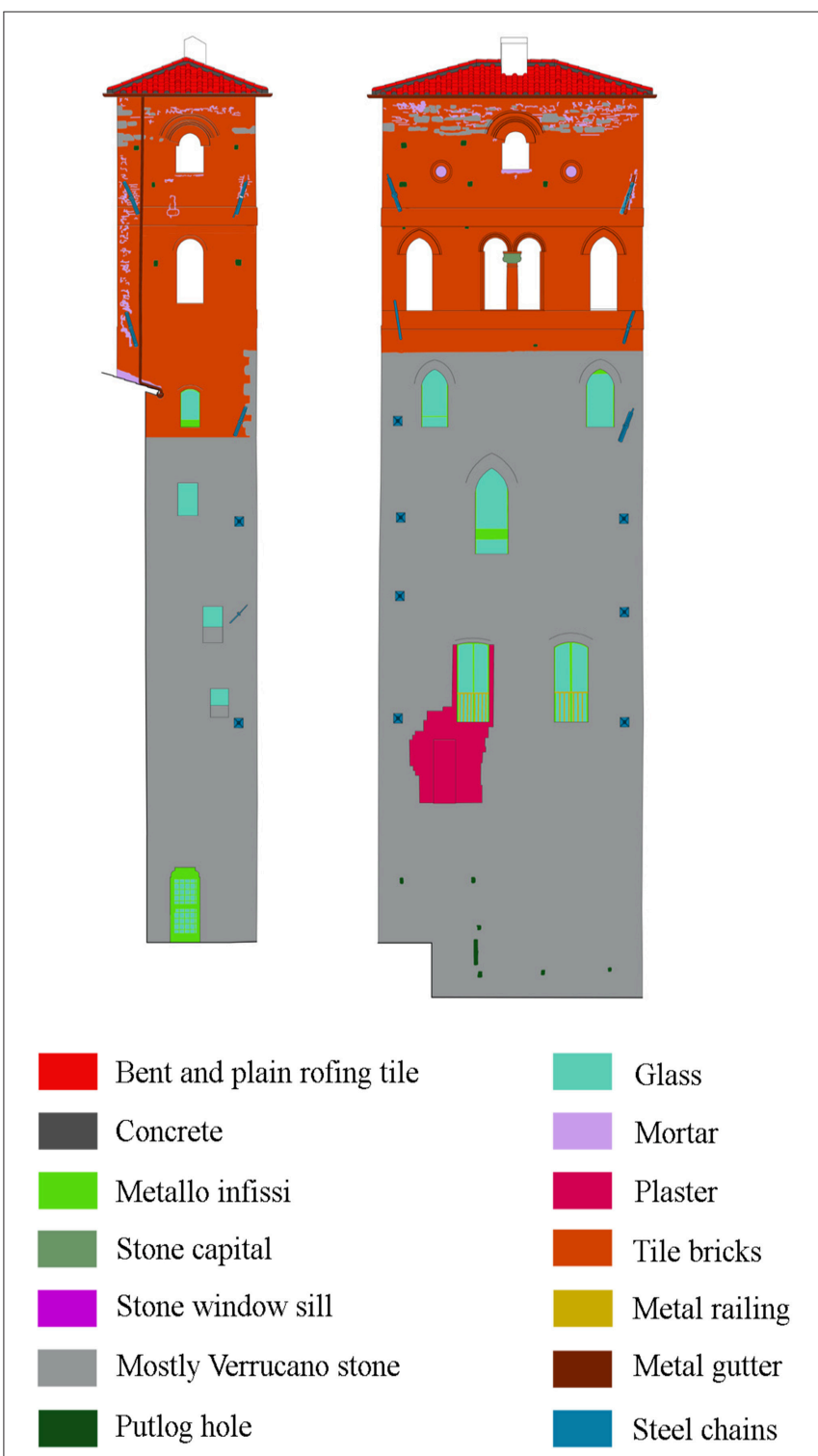

FIGURE 2 | Material analysis on the east and north façades of the Lanfreducci Tower. 


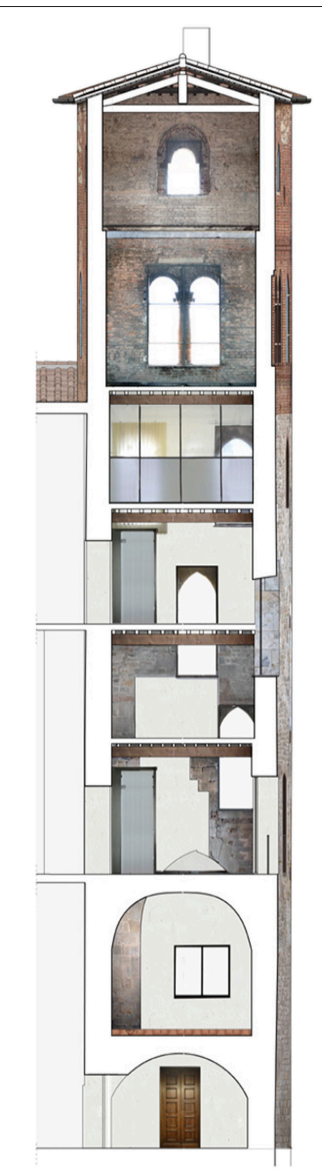

B'-B

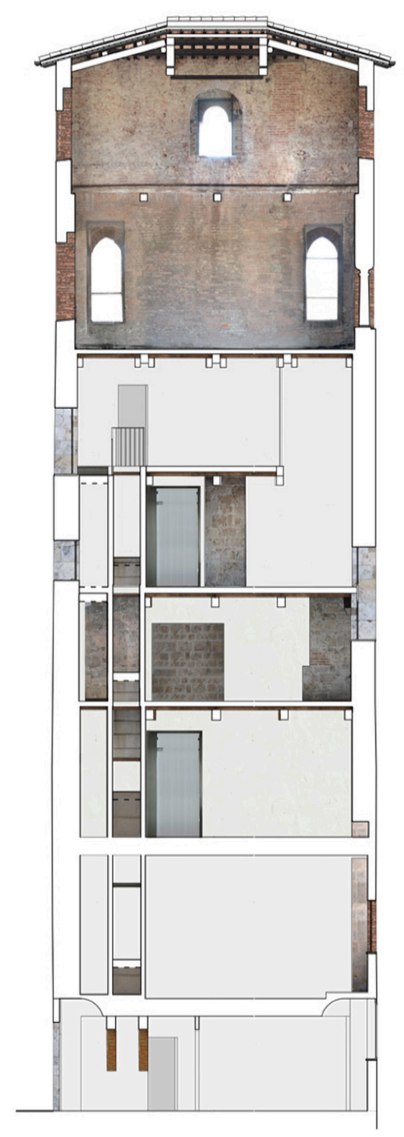

A-A
FIGURE 3 | Sections of the Lanfreducci Tower.

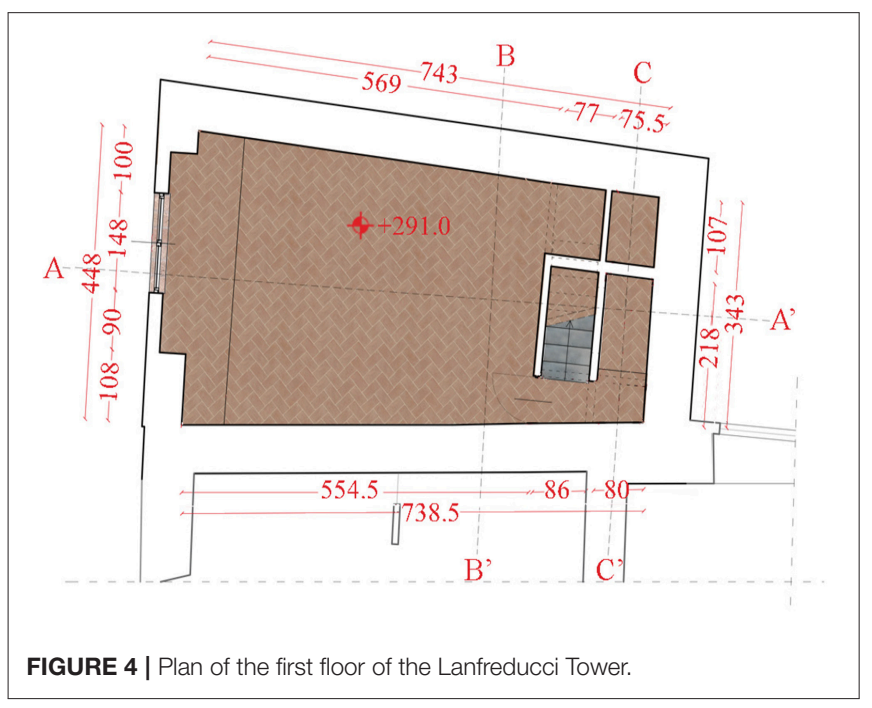

In the case of cultural heritage, the key to success in achieving meaningful results close to reality is to develop an integrated approach that is a combination of "qualitative" and "quantitative" methods: the first ones are based on activities

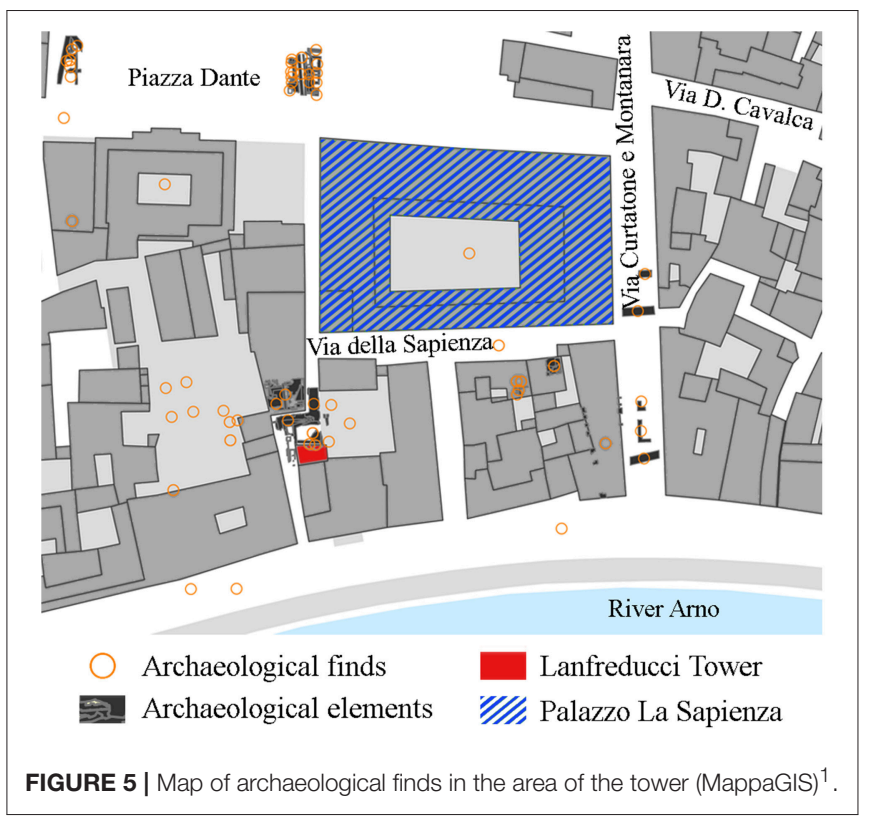

providing proper knowledge of the structure, allowing the deep understanding of the main structural and morphological features; the second ones are based on the application of one or more vulnerability assessing methodologies, including simplified mechanical methods and/or the use of numerical modeling and analysis. The qualitative approach is the fundamental part of structural assessment, needed to achieve reliable results and to identify the weakest areas of the buildings requiring an in-deep approach. The knowledge phase is the "framework" where the structural assessment is selected and organized, being fundamental the characterization of the constructive system, floor typologies, structural element geometry, information concerning foundation, geotechnical and geological characteristics of the soil, mechanical material properties, damages or restoration works that eventually happened in the past, local mechanisms that could be potentially activated (ICOMOS, 2005; D'Ayala et al., 2008; Bosiljkov et al., 2010; Caprili et al., 2015; Cattari et al., 2015; Castori et al., 2017). The degree of details of the knowledge phase and the typology of information collected should be calibrated based on the analysis that needs to be performed. Accounting for the peculiarities of historicalmonumental buildings, a common knowledge multistep and multilevel procedure is defined, able to highlight criticisms and deficiencies fundamental for the organization of a reliable structural assessment.

\section{Historical Analysis}

The genesis of a monumental building is a complex process taking place over centuries through modifications, alterations, aggregations of new portions, collapses, and rebuilding; these actions were not usually recorded in historical documents or drawings; sometimes their memory was lost over time

\footnotetext{
$\overline{{ }^{1} \text { MappaGIS, editor. Ritrovamenti. }}$.
} 

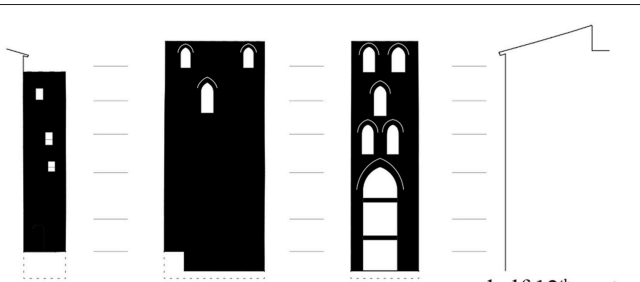

half $12^{\text {th }}$ century
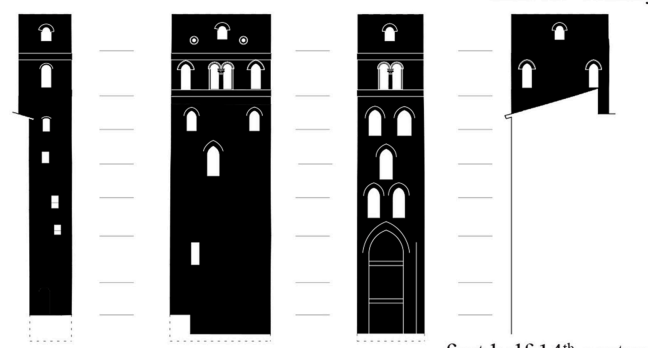

first half $14^{\text {th }}$ century
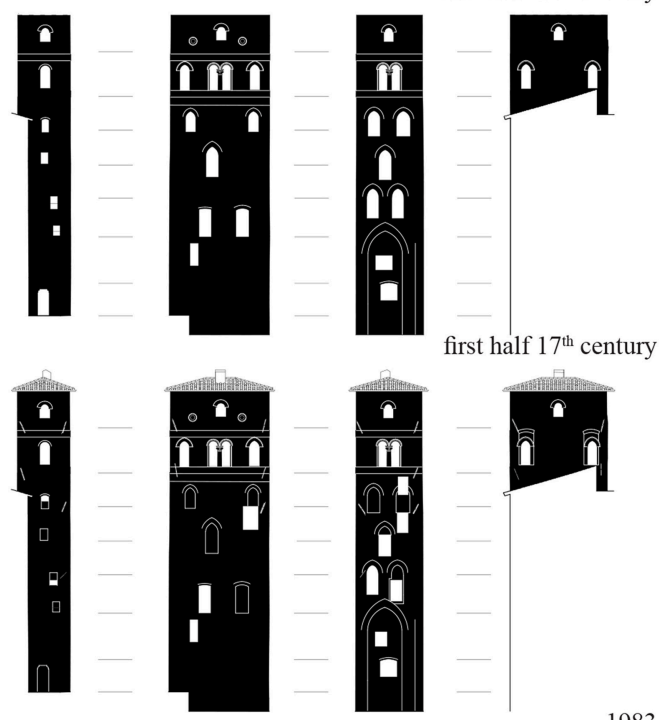

(1)
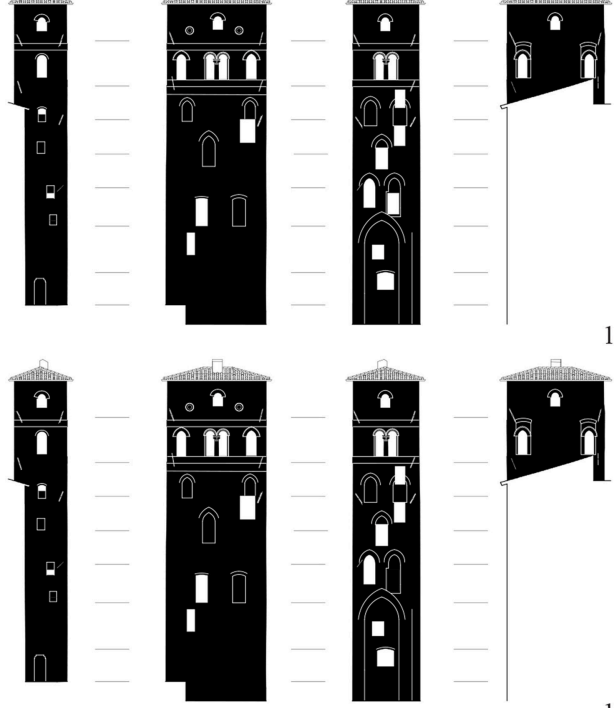

1983
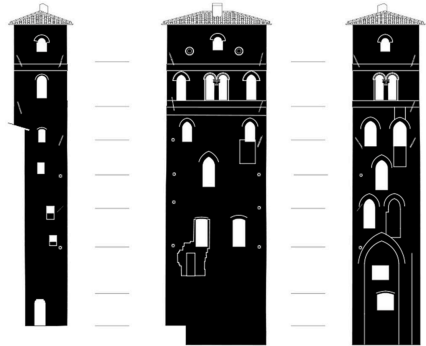

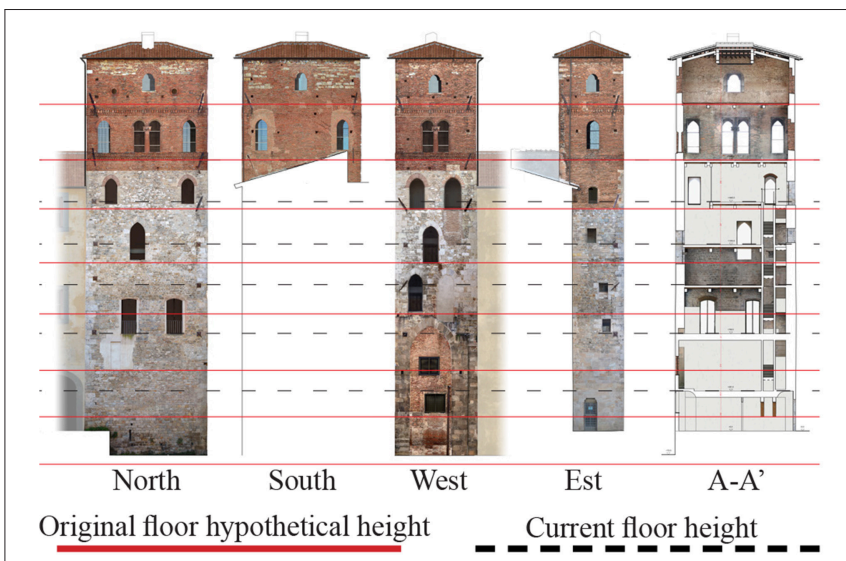

FIGURE 7 | Comparison among the actual and the original floor height of the Lanfreducci Tower.

as result of spontaneous and unplanned processes, making their presence not clearly recognizable. The critical-historical analysis allows the reconstruction of the construction and morphological evolution, pointing out areas of structural discontinuity and individuating past collapses or damages due to exceptional actions (e.g., past seismic event) or structural inadequacy, allowing to identify the weakest portions of the building or the mechanisms still ongoing. This result could be achieved crossing and comparing data coming from different sources such as bibliographic and archive research; study of historical documentations and cartography (e.g., cadastral maps, IGM maps); analysis of images of the building coming from paintings or frescoes, which could show, in a more or less reliable way, the characteristics of a specific historical period; critical analysis of masonry stratigraphy; and analysis of the architectonic features coming from in situ inspections (Augusti et al., 2001; Cattari et al., 2015; Berto et al., 2017). The critical-historical analysis allows to identify the structural units composing the overall aggregate, including the understanding of the mutual interrelationship resulting in different boundary conditions (Berto et al., 2017). By this way, it is possible to determine criticisms and vulnerabilities characterizing the building seen as a "structural aggregate" and analyze how the different structural units can influence each other in the whole performance (Caprili et al., 2017). The results of the morphological evolution are used to plan the in situ investigations in a rational and optimized way, deepen the efforts in correspondence with those areas affected by highest uncertainties, criticisms, overlapping of structural parts derived from different constructive phases, or evident structural weaknesses. The determination of past damages or previous restoration works could suggest structural deficiencies to be solved. Further, it helps in indentifying local mechanisms potentially activating, that cannot be adequately considered through global model and analysis (Binda and Saisi, 2005; Caprili et al., 2017).

The critical-historical analysis therefore allows to minimize the human impact on existing monumental buildings, where the artistic and architectural value shall be preserved (Cattari et al., 2015). 


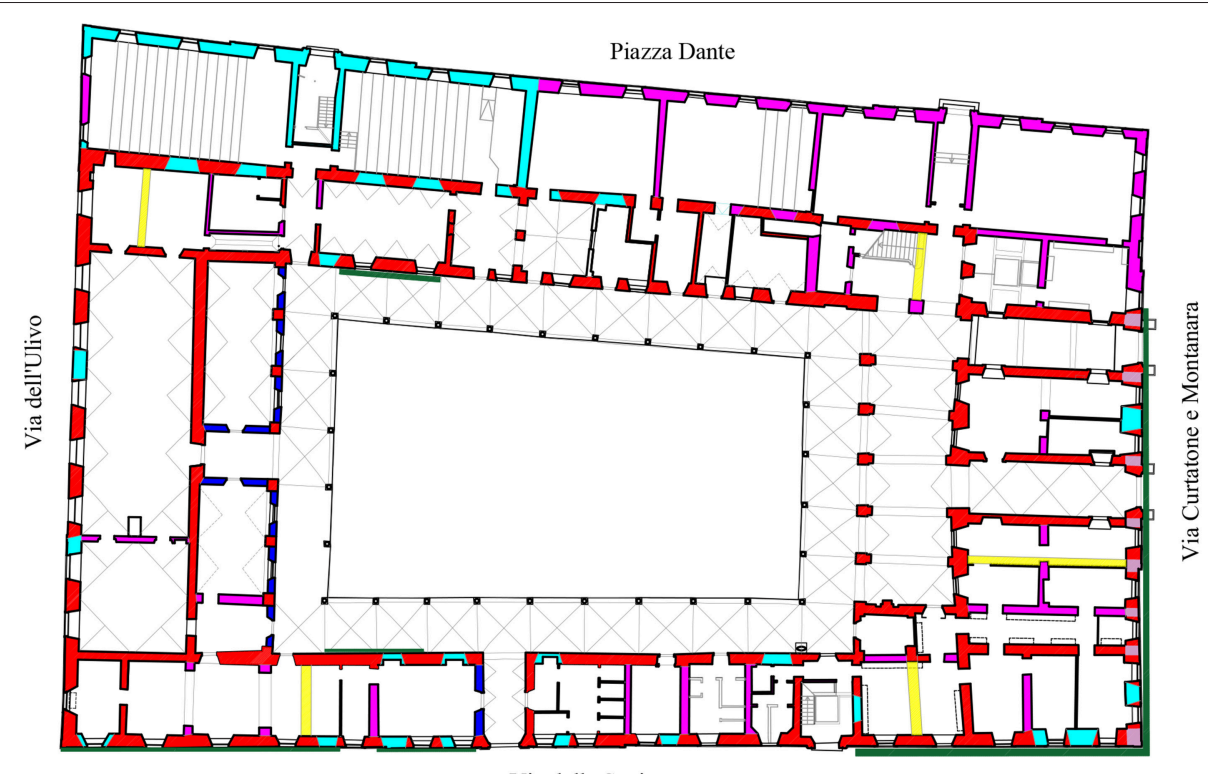

Via della Sapienza
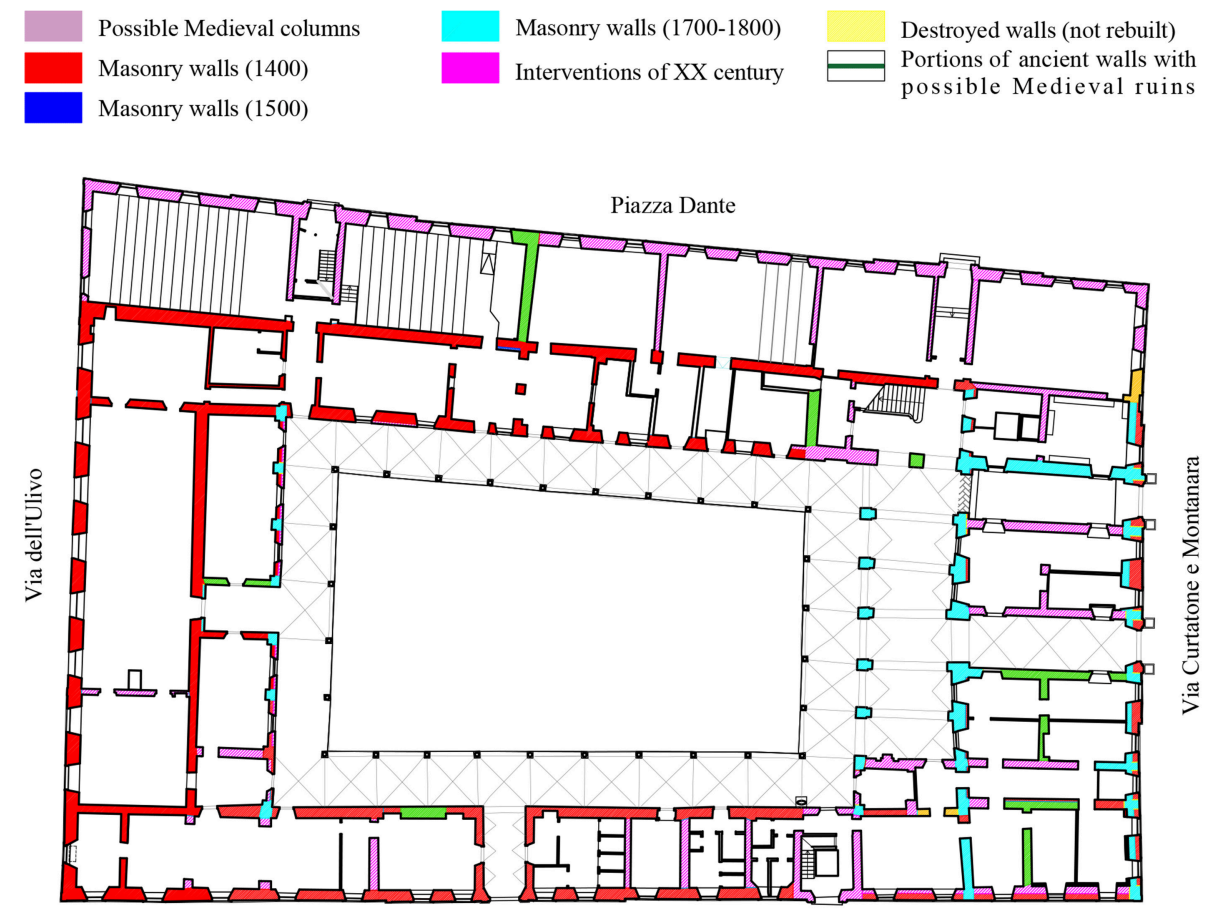

Via della Sapienza

Full bricks

Full bricks \& irregular split stones

Full bricks and squared stones

Full bricks \& rough-hewn stones

Full bricks and squared stones

with courses

Irregular stones

FIGURE 8 | Hypothesis of the evolutive development of the La Sapienza Palace and plan of ground floor with indications of the various types of masonry (Caprili et al., 2017).

\section{In situ Survey}

The in situ survey includes several activities aimed at collecting information concerning the global geometry of the building (in plan and in elevation), the structural characteristics of elements and details, the mechanical characteristics of materials, and the geotechnical features. This information allows to recognize the bearing system of the building, determining the entity of loads acting on elements and understanding the structural performance toward vertical and horizontal actions. Direct survey of masonry walls, horizontal stories and roof 

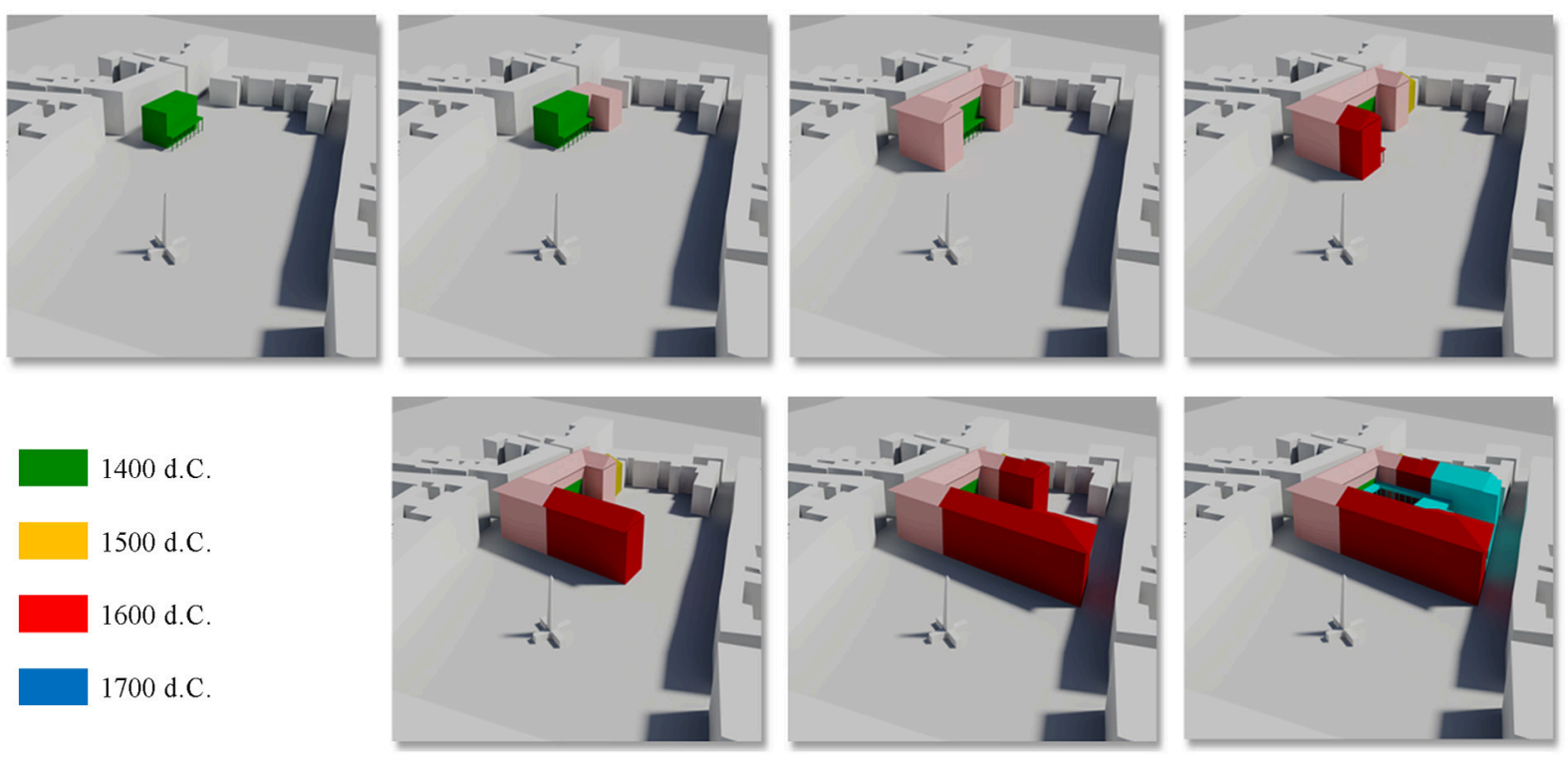

FIGURE 9 | Hypothesis of the morphological evolution of Palazzo Ducale.

stratigraphy, nonstructural elements including infills, structural asset, etc., is needed; data shall be collected by means of different tools, according to the budget available, the complexity of the structures, and the information coming from original documentation, allowing reduction of the in situ effort and minimizing the impact on cultural heritage.

Measurements can be made directly, as well as by means of tools such as a terrestrial laser scanner or drones, being as accurate as required in relation to the analysis that will be performed on the structure (Salonia et al., 2007; Fortunato et al., 2017). The analysis of the global geometry includes all the relevant aspects for the building structural response, such as the relationship with adjacent buildings-affecting the dynamic response and could cause building pounding, the presence of geometric irregularity in plan or elevation-influencing the irregular mass distribution, leading to an uneven dynamic response and the presence of thrusting structures-especially where ties are not introduced. Presence of untied mezzanines needs to be investigated because it is often characterized by lack of lateral force-resistant system, representing potential collapse elements whose stability needs to be checked. Irregular distribution of nonstructural elements, such as masonry partition walls and arcades or pillars alignments behaving as a soft story are surveyed (D'Ayala et al., 2008). Concerning structural details, as function of the complexity of the building, several information cannot be directly measured and needs to be defined based on reliable assumptions and considerations, also accounting for the information provided by the reconstruction of the morphological evolution process.

Masonry wall identification is performed by removing plaster portions to identify the masonry texture, its state of conservation, and the quality of the connection among perpendicular walls and among walls and floor, with attention to the eventual presence of artistic paintings to be protected. Endoscopic examinations allow the measurement of the wall thicknesses and the individuation of cavities, filling, metal insertions, or adjacent facings of different thicknesses or typologies (Roca et al., 2010; Caprili et al., 2017). The information achieved in this knowledge step should be compared and should integrate the results of the historical-critical analysis to reconstruct the building morphologic evolution (D’Ayala et al., 2008).

The material characterization can be achieved directly through the execution of in situ nondestructive or partially destructive tests, determining the mechanical properties (in terms of strength and elastic moduli) needed for structural assessment. The organization of experimental tests should take advantage of historical analyses, with the aim of characterizing all the relevant masonry typologies in relation to the age of construction. The determination of mechanical characterization based on results presented in the current scientific literature is also possible, if supported by adequate reasons (Binda et al., 1999a; Bosiljkov et al., 2005; Borri and De Maria, 2009; Magalhães and Veiga, 2009; Vasconcelos and Lourenço, 2009; Bosiljkov and Kržan, 2012). Geotechnical aspects are of relevant importance to characterize the foundation settlement and the types of soils and for the following analysis of seismic action and soil-structure interaction. The execution of local seismic response analysis could be performed as well, starting from the dynamic characterization of the foundation soil (Caprili et al., 2017).

\section{Analysis of the Cracking Scenario}

The survey of the cracking scenario and of the deformation pattern includes information concerning type, geometry, and layout distribution of cracks in the building and presence 


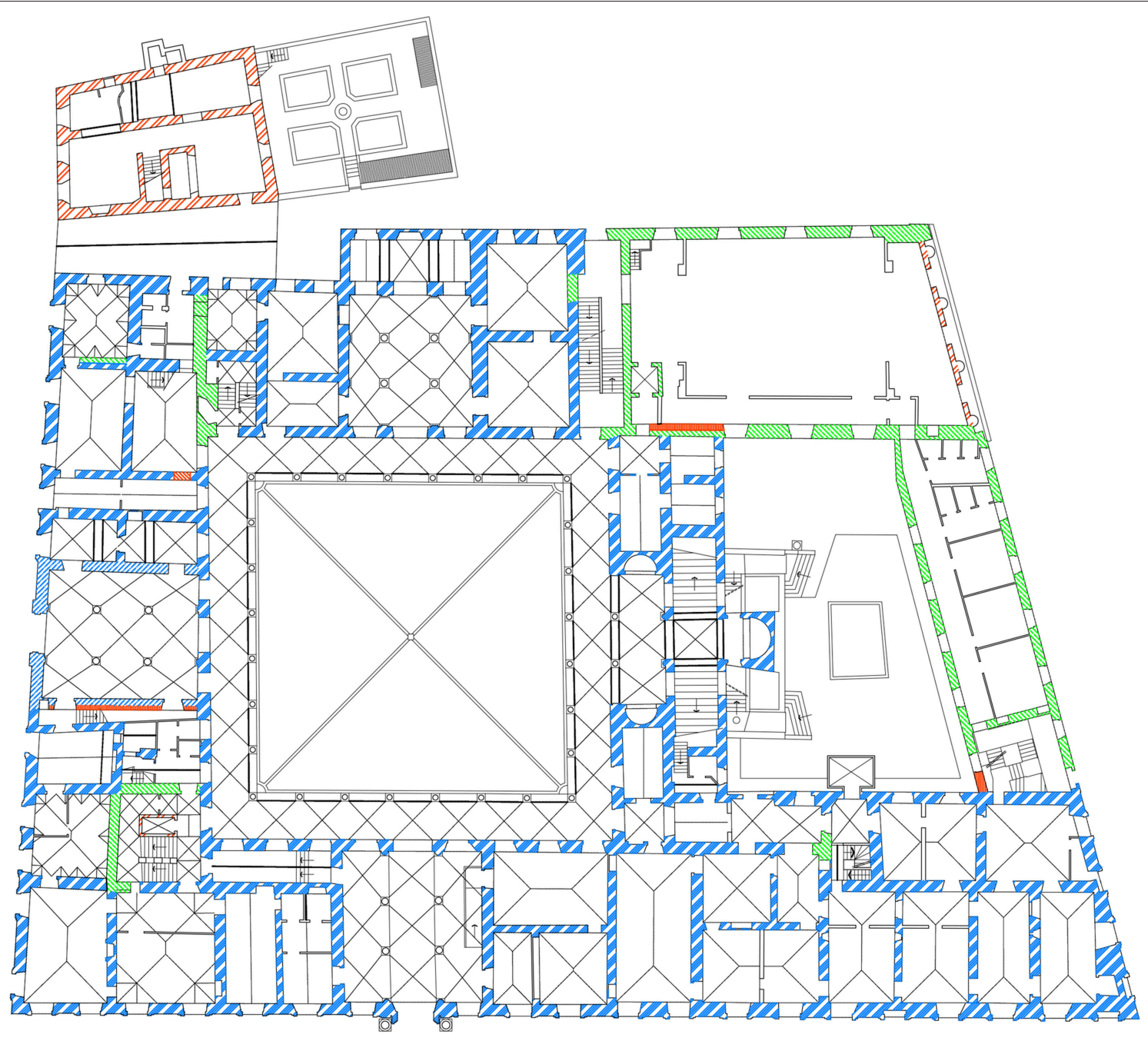

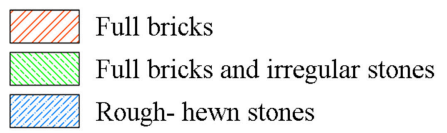

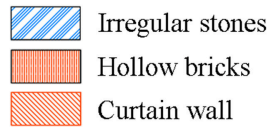

Non detectable masonry

Cavity

Curtain wall

FIGURE 10 | Masonry typologies surveyed in Palazzo Ducale.

of cracks and out-of-plumbs. The identification of structural irregularities such as rotations, vertical deviations, or loss of horizontality in load-bearing elements is also needed, especially in a refined analysis (Binda and Saisi, 2005). These activities could be performed by means of inspections and, if needed, removal of plaster portion and are important to identify settlement movement of the structure or local mechanisms that can potentially activate. In the phenomenon-involved areas, the greater number of in situ investigations, with the aim of performing more accurate analysis, can be concentrated. By comparing the information collected with the historical-critical analysis (e.g., past collapses, damages, past seismic events) and that with the structural analysis (e.g., structural deficiency, lack of quoins), the understanding of the reasons of local failures and collapses or damages is possible (Avorio and Cangi, 1999; Borri et al., 1999; Bartoli et al., 2000; Casarin and Modena, 2008), together with the organization of a continuous or step-by step monitoring system to analyze the development of relevant displacements (Binda and Saisi, 2005).

\section{Structural Analysis and Evaluation of Seismic Assessment}

The knowledge phase represents the qualitative contribution to the vulnerability assessment procedure; once completed, enough information for the execution of the quantitative approach has been collected. The potentially achievable local mechanisms, previously identified combining the 

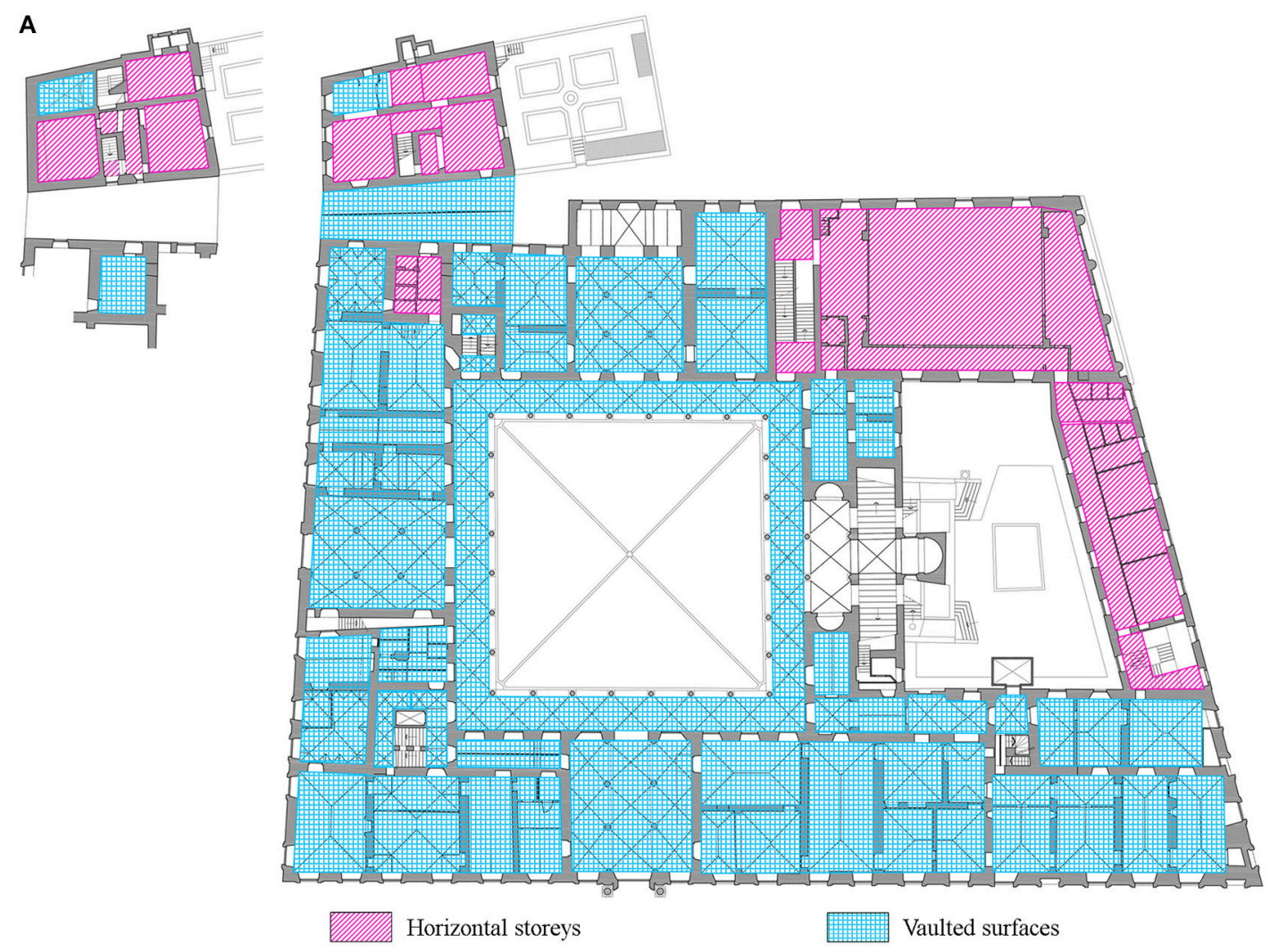

B

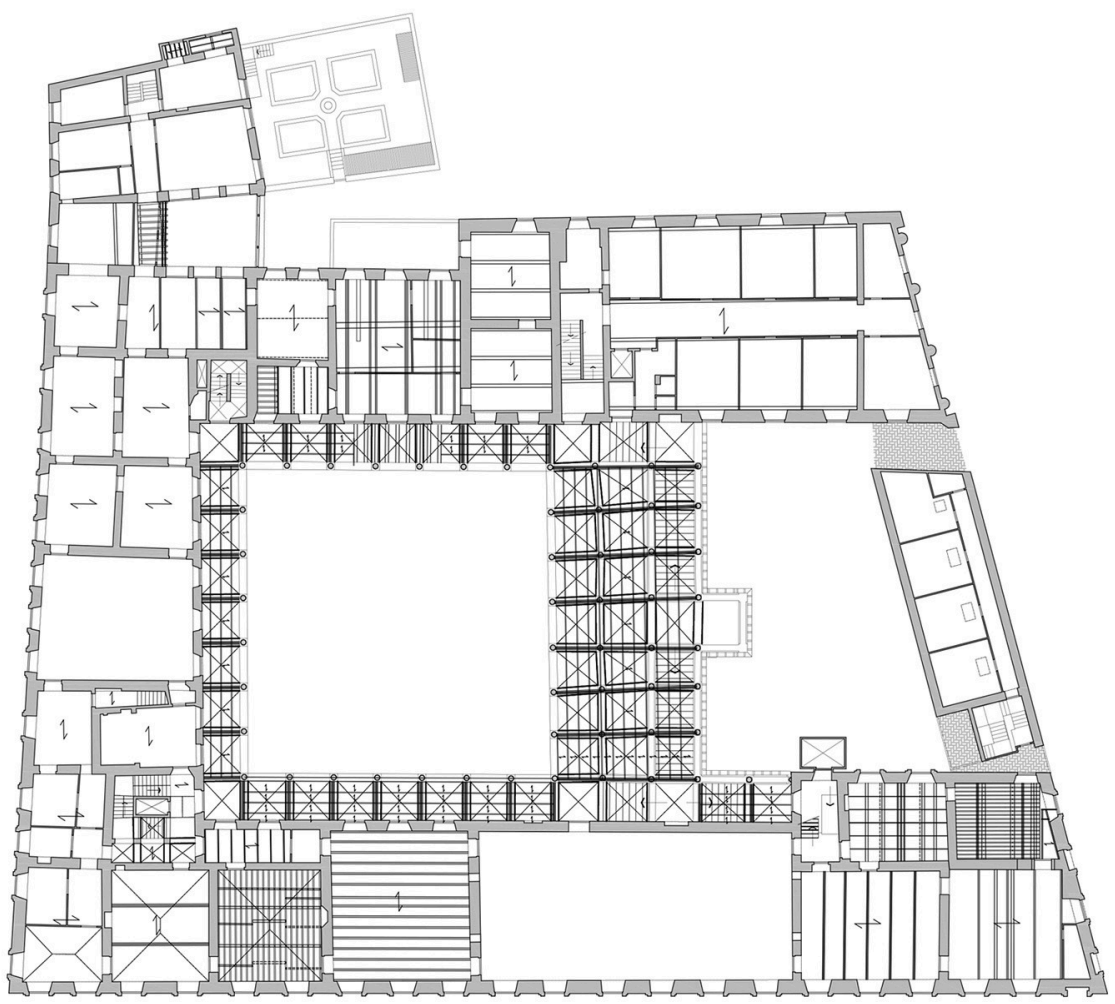

FIGURE 11 | (A) Floor typologies (flat or vaulted) surveyed in correspondence to the second level of Palazzo Ducale. (B) Floor typologies surveyed in correspondence to the third level of Palazzo Ducale. 
Floor at the third level of Palazzo Ducale, partially composed by timber- frame structures and partially composed by steel-frame structure.
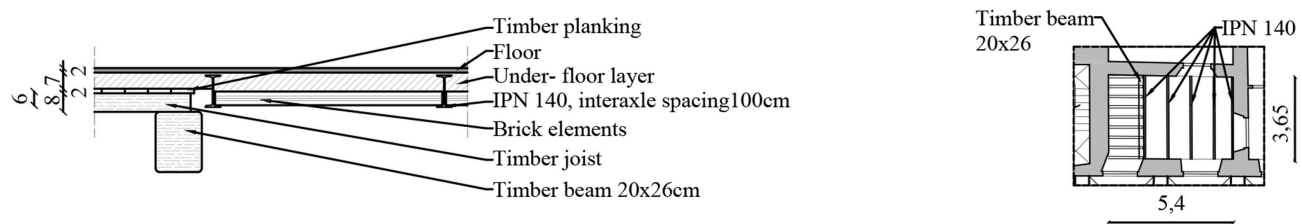

Floor at the third level of Palazzo Ducale, composed by steel-frame structure. It is still partially present a previous timber frame structure without bearing function.
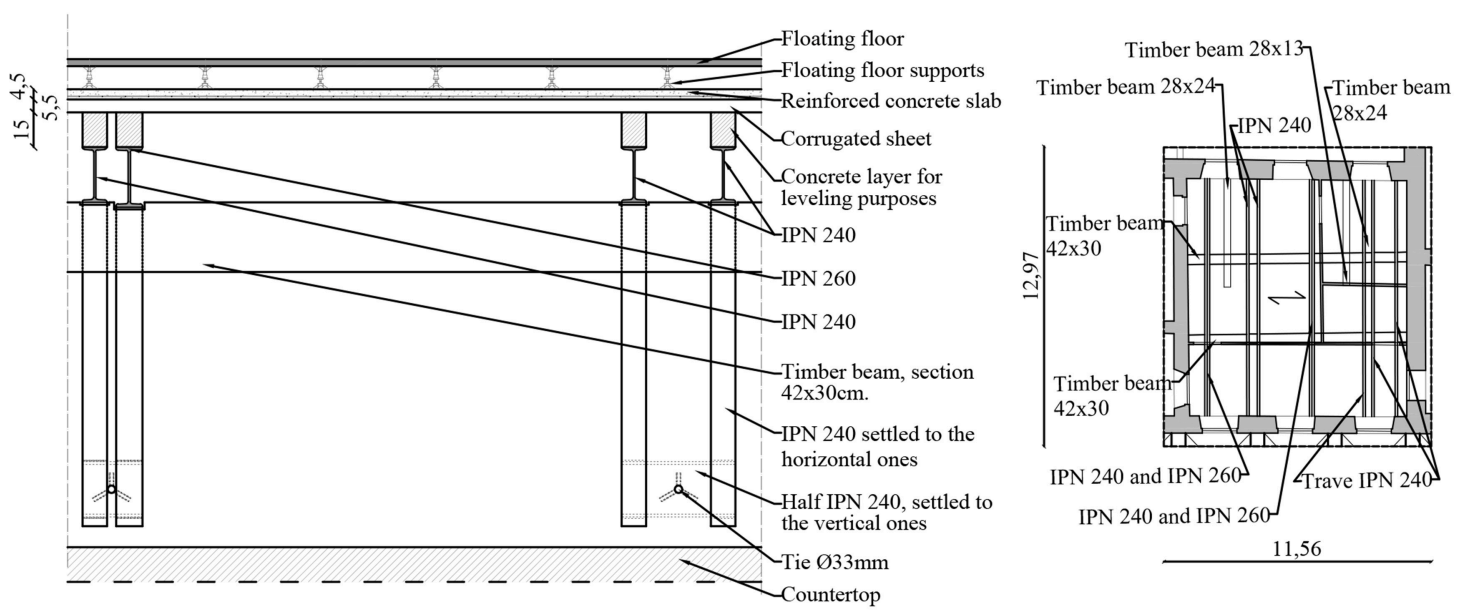

11,56

Floor at the third level of Palazzo Ducale, composed by steel-frame structure and brick joisits with reinforcement.

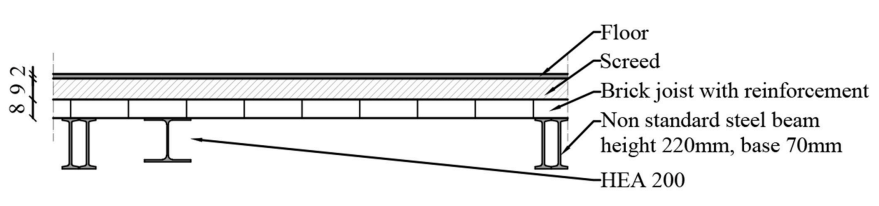

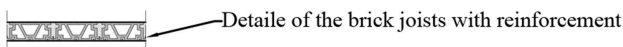

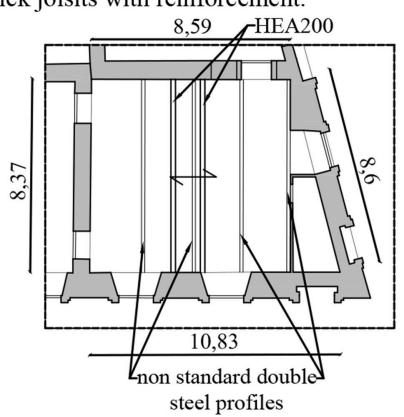

Vaulted floor at the first level of Palazzo Ducale.
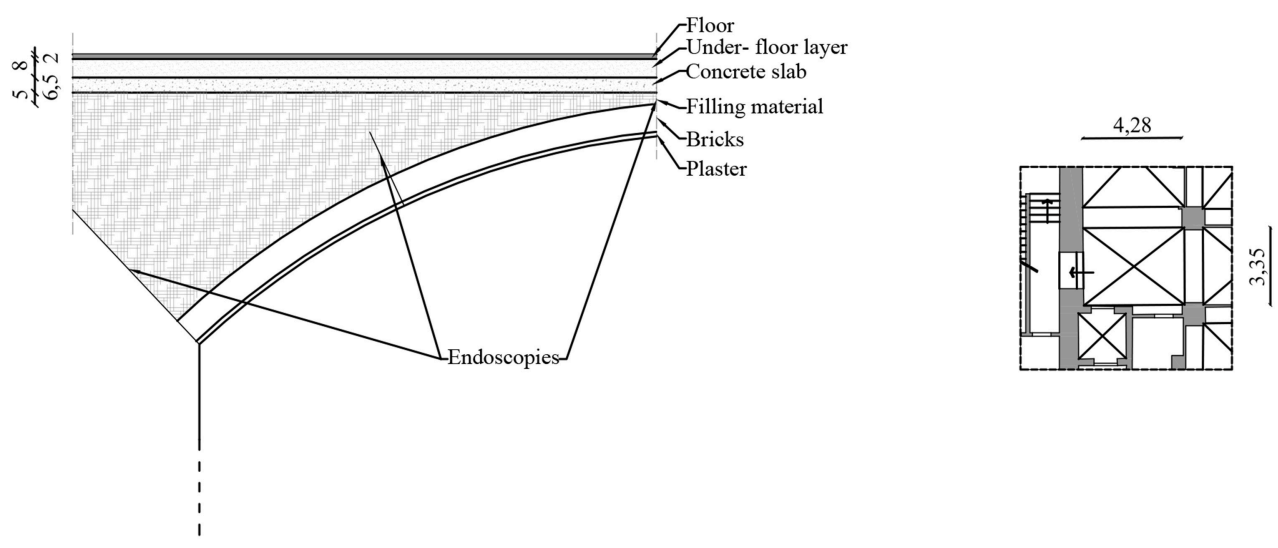

FIGURE 12 | Examples of structural details surveyed in Palazzo Ducale. 


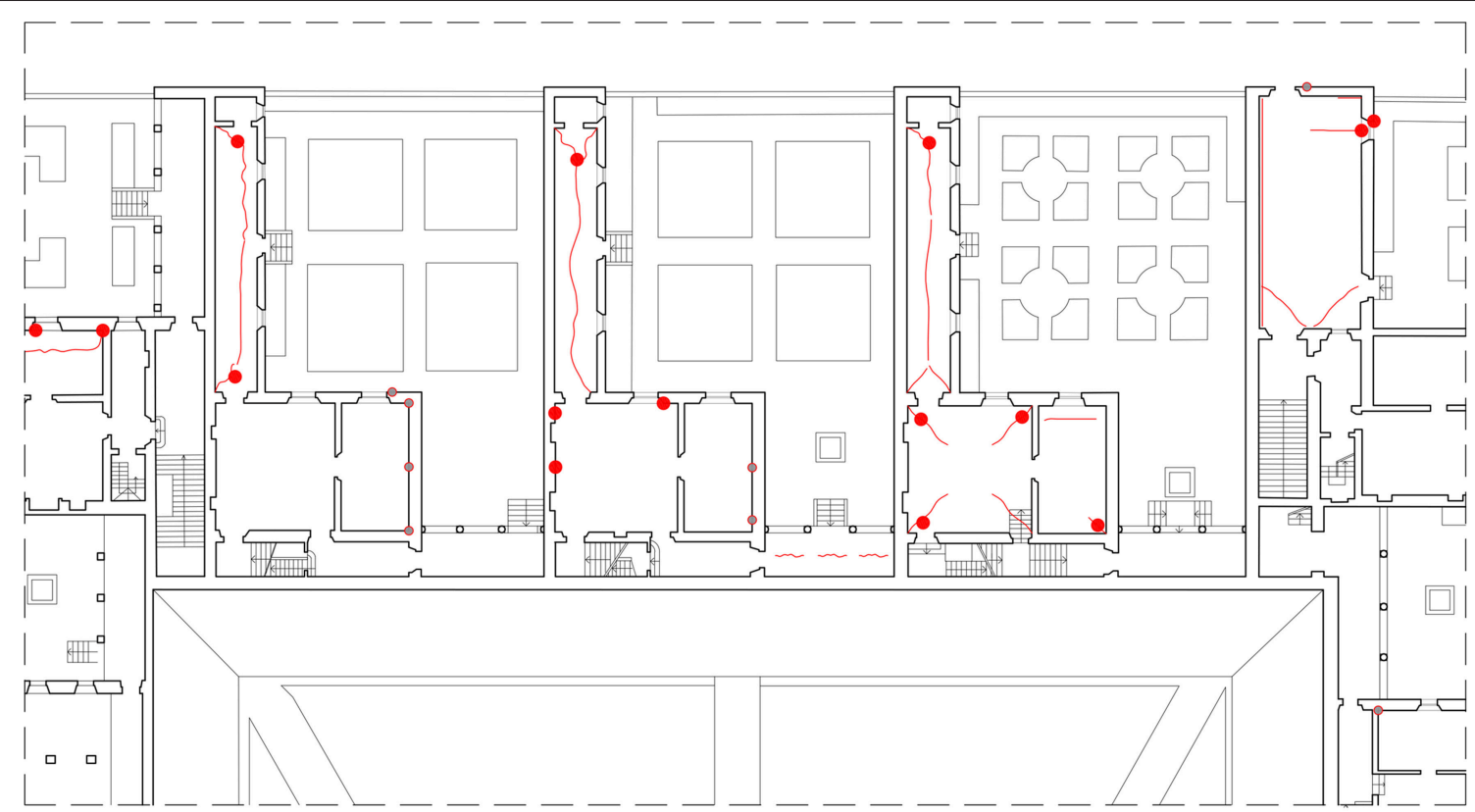

\section{Relevant cracks on walls \\ Light cracks on walls \\ $\sim$ Cracks on floors}

FIGURE 13 | Cracking scenario of a portion of the clauster in the Certosa of Calci.

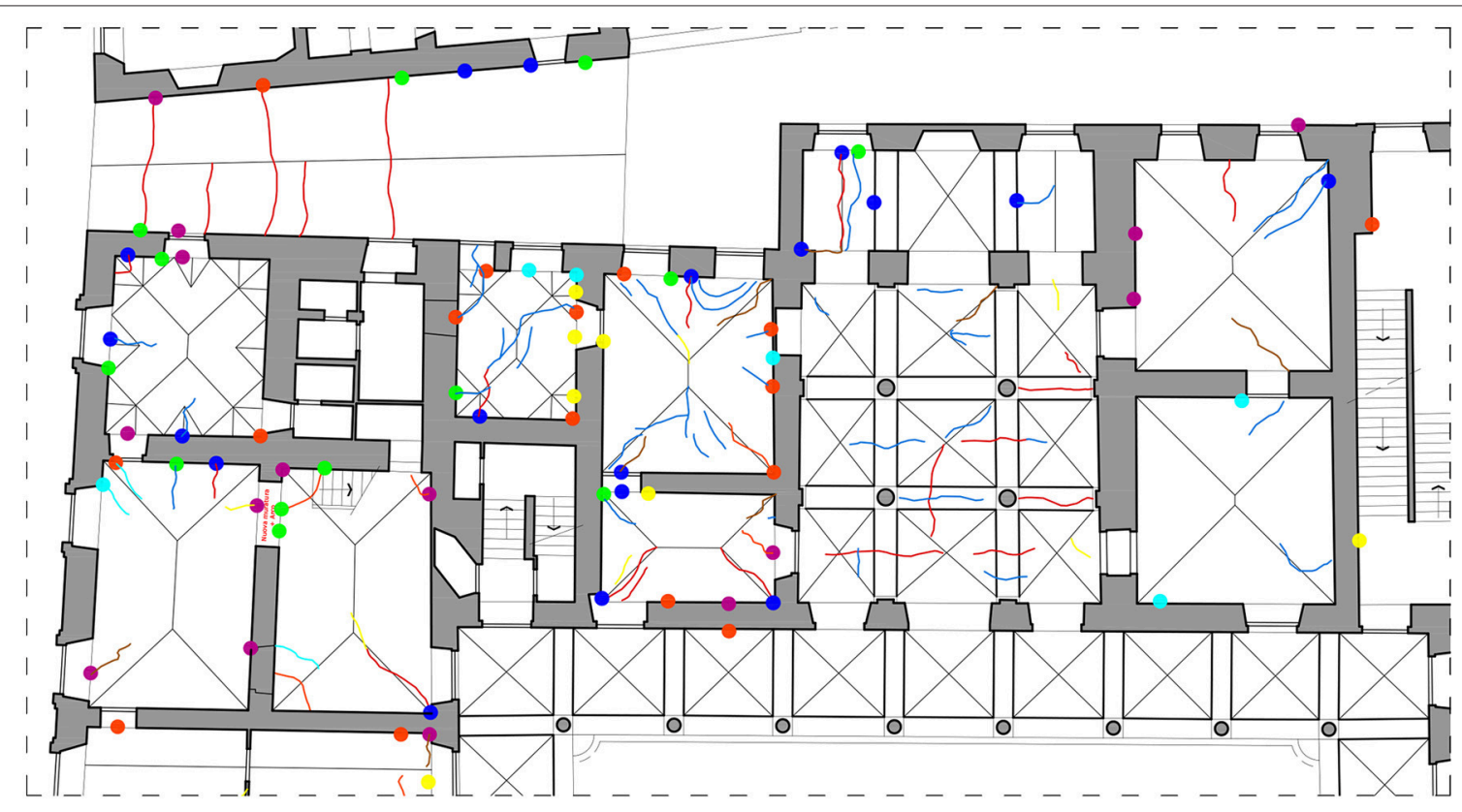

I survey: September 2012- crack on masonry

II survey: February 2013- crack on masonry

II survey: February 2013- light entity crack on masonry

III survey: June 2013- crack on masonry

III survey: June 2013- light entity crack on masonry

IV Survey: July 2013- light entity crack on masonry
I survey: September 2012- crack on ceiling

II survey: February 2013- crack on ceiling

II survey: February 2013- light entity crack on ceiling

III survey: June 2013- crack on ceiling

III survey: June 2013- light entity crack on ceiling

IV Survey: July 2013- light entity crack on ceiling

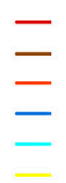

FIGURE 14 | Cracking scenario of a portion of the Palazzo Ducale. 


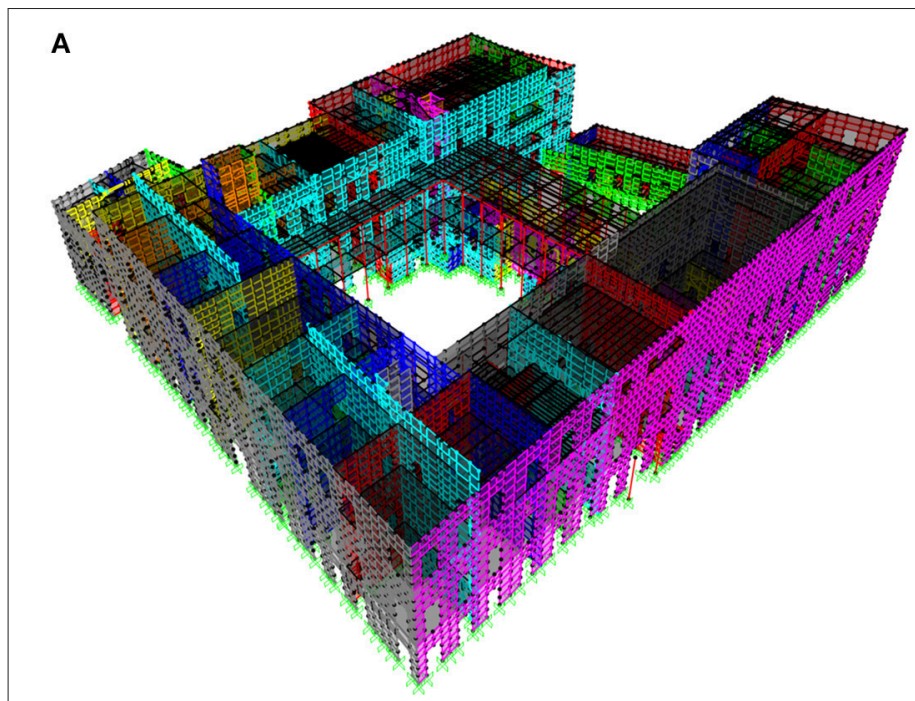

B

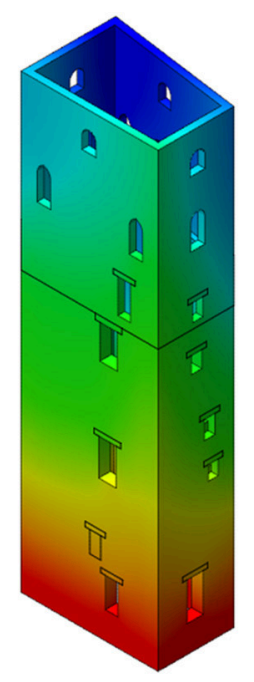

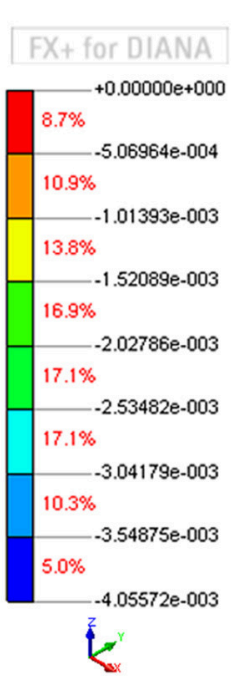

FIGURE 15 | Examples of 3D numerical models realized based on the information collected in the knowledge phase. (A) Palazzo Ducale; (B) Torre Lanfreducci.

morphological evolution and the determination of independent structural units/portions/elements and the in situ survey of the evident cracking scenario, should be analyzed. Local problems can enable the development of a global building behavior, causing serious damage even for low-intensity earthquakes or, in general, in the presence of relevant quasistatic horizontal thrusts. Simplified techniques, such as the already mentioned macro-element analysis, linear or nonlinear kinematic analysis, or other procedures suggested in the current scientific literature (Borri et al., 1999; Orduña and Lourenço, 2001; Milani, 2013; Rossi et al., 2015; Circolare, 2019), can be adopted. Global analyses on the whole building, with numerical models realized based on the knowledge achieved according to the information previously collected, are meaningful only if the activation of local failures has been prevented, since otherwise the study of a global "box" behavior is not realistic.

\section{APPLICATION TO CASE STUDY BUILDINGS}

The relevance of the proposed methodology was appreciated within the structural assessment of four historical case study buildings located in the Tuscany region: the Lanfreducci Tower (Pisa, Italy), the Palazzo La Sapienza (Pisa, Italy), the Palazzo Ducale (Massa, Italy), and the Certosa of Calci (Pisa, Italy).

The Lanfreducci Tower is a medieval masonry tower located in the most ancient area of the city of Pisa, directly connected to the building "Alla Giornata." The tower is known with the name of the family that owned it for several centuries: the building was officially mentioned for the first time in a will in 1348, and the Lanfreducci family owned it until the end of the Nineteenth century. There were no official documents concerning the construction of the tower, and very few were contained information concerning the modifications undergone by the tower and by the whole surrounding urban area during the centuries. Palazzo La Sapienza is a monumental complex located in the city center of Pisa, very close to the Lanfreducci Tower. The structure was the result of the progressive aggregations of several masonry units or tower houses to the medieval structure of Piazza del Grano and of Dogana del Sale, due to the creation of the house seat of the University of Pisa in the Fifteenth century. Relevant structural modifications (e.g., demolition of internal bearing walls, super-elevations, realization of new slabs, etc.) were performed in the Nineteenth century to enlarge the space for hosting the books of the University Library, causing structural diseases.

The Certosa of Calci is a monumental complex in a valley close to Pisa, whose construction began in 1366. At the end of the Fourteenth century, the first nucleus, including all the functions needed for a monk's life, was completed. Interventions and modifications were continuously carried out until the Eighteenth century, aiming at enlarging the building, creating more comfortable spaces, and embellishing, decorating, and harmonizing the complex. In the Nineteenth and Twentieth centuries, retrofit was performed to adapt the building to new intended uses (e.g., military barracks, war hospital, and museum).

Palazzo Ducale is located in the center of Massa. The first unit of the building dates to the Fifteenth century with the construction of a small rectangular-shaped dwelling aimed at being a hunting residence for the Malaspina, a noble family that ruled around the town. During the Sixteenth century, several modifications, not well documented, enlarged the building size, up to the Seventeenth century when the palace reached the appropriate size for a noble residence and was supplied of representative rooms. In the following centuries, the works proceeded, giving the palace the actual configuration.

The drawings, the structural sections, and the plans of the different levels of the Lanfreducci Tower are presented in Figures 1-4. The architectural/geometrical survey was 
performed using both traditional instruments and total station/theodolite technique, allowing to achieve an accurate and reliable organization of masonry walls and horizontal stories both in plan and in elevation. The information coming from the historical analyses, mainly concerning the construction phases, was validated using the results of the in situ surveys. Archaeological findings (Figure 5) as well as cadastral maps were analyzed to date back the construction birth and to understand the influence of the urban area on the buildings' evolution. Based on the historical information and architectural features-e.g., materials, windows' shape, typological characteristics of medieval towers, presence and typology of decorations, etc.-hypotheses about the morphological evolution of the tower were formulated (Figure 6), allowing to reconstruct the original stories' height (Figure 7). Masonry typologies were visible from the outside, differently with respect to the other cases, well highlighting the different construction phases and their correspondence with historical findings.

In the cases of more complicated buildings, such as, for example, the Palazzo La Sapienza or the Palazzo Ducale, masonry typologies were not directly visible, and more investigations were needed to allow the correspondence among construction phases and mechanical characteristics of materials to be used in the numerical modeling and structural assessment (Figures 810). More invasive techniques, such as removal of plastic portions, were adopted beyond the visual inspections, and, in both cases, the surveys were spread all over the buildings to have an overall idea of the masonry typologies, concentrating actions where the historical analysis located discontinuity areas, criticisms, etc.

Similar considerations shall be made concerning horizontal stories, whose bearing capacity is an important parameter for the structural assessment of the whole structure, taking also into account that the knowledge of their characteristics (in terms of thickness and weight of different layers) is needed for the numerical modeling. In the case of the Palazzo Ducale di Massa, a lot of different floor typologies were found due to the great interventions' stratification. In the first and second building levels, there was a prevalence of vaulted surfaces: barrel or pavilion vaults were detected mainly in wide spaces, while cross vaults characterized little spaces (Figure 11). An irregular stone-brick masonry bearing layer characterized most of the vaults on the first level, while a one-brick-thick bearing layer characterized most of the vaults on the second level. Endoscopic investigations, performed in different vault sections, allowed to define the thickness of the bearing layer and of the filling material, which changed significantly according to the different vaults. The density of the filling material was opportunely measured not to under(or over)estimate permanent loads. In the third and fourth levels, horizontal stories with different bearing elements were found, such as steel frames, timber frames, and precast reinforced concrete, introduced as a consequence of different retrofit operations. For example, steel frames were often introduced in timber frame structures to increase the bearing capacity and/or to limit high deflections. Interest was paid to brittle elements, which could represent a criticism, such as brick joists with or without reinforcement, as well to identify frames with insufficient support length in the wall. An extended in situ survey campaign was planned to investigate all the typologies of horizontal structures by defining the floor stratigraphy, the geometrical size, and the structural characteristics of elements. For each investigation, structural sections (Figure 12), useful for the modeling, were provided.

Information resulting from the cracking scenario survey joined with other indications coming from old documents, structural retrofit, etc., leads to the identification of local mechanisms and to the comprehension of the possible causes of the detected phenomena. The cracks' layout represents a valid tool to understand the structural behavior and to recognize phenomena such as vertical wall overturning, collapse of the upper portion of the facade, separation and expulsion of the corners, and so on. For instance, in the case of the Certosa of Calci, the analysis of the cracking scenario in the cluster cells had highlighted a crack prevalence in the long rectangular body instead of in the smallest ones (Figure 13). That difference was probably since the two bodies of the cells were not built in the same period and with the same masonry typology and since there was a phenomenon of subsidence of the land that facilitates a rotational phenomenon. Land subsidence phenomenon, when detected, need to be investigated in-depth because it could seriously affect the structural response of the building. The visual recognition performed for the Lanfreducci Tower did not highlight important cracks, resulting in a nonsignificant cracking scenario, a possible consequence of recent maintenance operations carried out over the past decades, being the Tower was used as headquarters of the rectorate of the University of Pisa. Palazzo La Sapienza, as evidenced in Caprili et al. (2017), highlighted a cracking scenario characterized by an irregular distribution of medium-high damages mainly located in correspondence with those areas where the highest modifications toward the centuries took place: as an example, the corner between Via Curtatone e Montanara and Via della Sapienza suffered from the differential displacements caused by different settlement of foundations and from the presence of different masonry typologies (e.g., stone columns of ancient tower houses, masonry panels, etc.). This situation evidenced the strict relationship existing between the morphological and historical development of the aggregate and its structural response. A periodical monitoring of the cracking scenario was performed for Palazzo Ducale, because of the small damages and cracks that became visible after the earthquake event of May 2012. This procedure was adopted to understand if the building was-or not-subjected to ongoing phenomena, potentially representing a structural problem since connected to in-progress relative displacements. As presented in Figure 14, four survey campaigns were executed from September 2012 to July 2013, highlighting an ongoing crack phenomenon, probably a consequence of the earthquake of Emilia Romagna and still in progress.

The application of the proposed multistep procedure granted reliability to the $3 \mathrm{D}$ numerical finite element models, realized for the execution of the analyses, adopting, for example, the models represented in Figure $\mathbf{1 5}$ based on a deep and in situ knowledge of the construction analyzed. 


\section{CONCLUSIONS}

In the present paper, a knowledge-based approach for the analysis of historical-monumental buildings is presented and applied to four case studies of relevant importance located in the Tuscany region. Historical-monumental buildings are generally characterized by great complexity due to a long and not homogeneous constructive process, which results in the buildings being characterized by the interaction of several "structural units" whose behavior determines the structural response of the overall complex. Because of this complexity and to the general lack of information typical of this kind of buildings, all the methods for the evaluation of the seismic vulnerability should be associated to a deep and accurate knowledge phase in order to provide reliable results when structural assessment is performed.

A multidisciplinary and multilevel knowledge procedure has been proposed and tested on case studies with the aim of providing a tool easy to adapt in all typologies of monumental buildings, respecting their peculiarities and their uniqueness. The procedure is based on three main steps able to achieve information concerning morphological evolution, geometry, structural details and typologies, material mechanical characteristics, ground characteristics, possible local mechanisms, and deformation. In this way, it is possible to reconstruct a geometrical-structural model of the building able in pointing out structural units, in comprehending the typology of connections among them, and in recognizing the weakest areas of the overall building, which needs to be investigated and analyzed in-depth. In the framework provided by the knowledge procedure, it is possible then to develop numerical models for carrying out complex analyses or to perform simplified analyses, according to one of the several methodologies provided by the current scientific literature, obtaining reliable results representative of the reality.

\section{REFERENCES}

Augusti, G., Ciampoli, M., and Giovenale, P. (2001). Seismic vulnerability of monumental buildings. Struct. Saf. 23, 253-274. doi: 10.1016/S0167-4730(01)00018-2

Avorio, A. B., and Cangi, G. (1999). "Meccanica del danneggiamento negli edifici storici: dall'osservazione diretta all'interpretazione strutturale," in Assisi '99 Seminario Internazionale e Workshop Il Comportamento Sismico del Patrimonio Edilizio nei Piccoli Centri Storici (Assisi), 22-24.

Baggio, S., Berto, L., Rocca, I., and Saetta, A. (2018). Vulnerability assessment and seismic mitigation intervention for artistic assets: from theory to practice. Eng. Struct. 167, 272-286. doi: 10.1016/j.engstruct.2018. 03.093

Barbieri, G., Biolzi, L., Bocciarelli, M., Fregonese, L., and Frigeri, A. (2013). Assessing the seismic vulnerability of a historical building. Eng. Struct. 57, 523-535. doi: 10.1016/j.engstruct.2013.09.045

Bartoli, G., Casamaggi, C., and Spinelli, P. (2000). "Numerical modelling and analysis of monumental buildings: a case study," in 5th International Congress on Restoration of Architectural Heritage (Florence).

Bernardini, A. (ed). (2000). La vulnerabilità Degli Edifici: Valutazione Ascala Nazionale Della Vulnerabilità Sismica Degli Edifici Ordinary. Rome: CNRGruppo Nazionale per la Difesa dai Terremoti.

\section{DATA AVAILABILITY}

All datasets generated for this study are included in the manuscript and/or the supplementary files.

\section{AUTHOR CONTRIBUTIONS}

SC and IP contributed to the design and implementation of this research, to the planning and survey of the in situ investigations, to the analysis of the results and to the writing of the manuscript.

\section{FUNDING}

This research was carried out in the framework of the project Studi conoscitivi e ricerche per la conservazione e la valorizzazione del Complesso della Certosa di Calci e dei suoi Poli Museali promoted by the University of Pisa (project coordinator, Professor Marco Giorgio Bevilacqua), of the research agreement Studi e Ricerche sulla Vulnerabilità Statica e Sismica del Palazzo Ducale a Massa between the Department of Civil and Industrial Engineering of the University of Pisa and the Province of MassaCarrara (Scientific Project Head, Professor Walter Salvatore) and in the framework of other collaboration with the University of Pisa.

\section{ACKNOWLEDGMENTS}

The authors are thankful to the University of Pisa, to the Superintendence BAPSAE of Pisa and Livorno, and to the province of Massa-Carrara for supporting and encouraging this research. The authors would like to thank the expert technicians Simone Cavallini, Mirko Donati, Giuseppe Chellini, and Michele Di Ruscio of the Laboratorio Ufficiale per le Esperienze sui Materiali da Costruzione of Pisa University for the execution of experimental tests on masonry structures, vaults, and story.

Bernardini, A., and Lagomarsino, S. (2008). The seismic vulnerability of architectural heritage. Struct. Build. 4, 171-181. doi: 10.1680/stbu.2008.161.4.171

Berto, L., Doria, A., Faccio, P., Saetta, A., and Talledo, D. (2017). Vulnerability analysis of built cultural heritage: a multidisciplinary approach for studying the Palladio's Tempietto Barbaro. Int. J. Archit. Heritage 11, 773-790. doi: 10.1080/15583058.2017.1290853

Binda, L., Baronio, G., Penazzi, D., Palma, M., and Tiraboschi, C. (1999a). "Caratterizzazione di murature in pietra in zona sismica: data-base sulle sezioni murarie e indagini sui materiali," in Atti del 9 Convegno Nazionale: Lingegneria Sismica in Italia, 20-23 Settembre 1999 (Turin).

Binda, L., Gambarotta, L., Lagomarsino, S., and Modena, C. (1999b). “A multilevel approach to the damage assessment and seismic improvement of masonry buildings in Italy," in Seismic Damage to Masonry Buildings (Rotterdam: Balkema), 170-195. doi: 10.1201/9780203740040-17

Binda, L., and Saisi, A. (2005). Research on historic structures in seismic areas in Italy. Prog. Struct. Eng. Mater. 7, 71-85. doi: 10.1002/pse.194

Borri, A., Avorio, A., and Cangi, G. (1999). "Considerazioni sui cinematismi di collasso osservati per edifici in muratura", in IX Convegno Nazionale "Lingegneria Sismica in Italia" (Turin: ANIDIS).

Borri, A., and De Maria, A. (2009). "L'indice di qualità muraria (IQM): evoluzione ed applicazione nell'ambito delle norme tecniche per le costruzioni del 2008," 
in Proceedings of 13th Italian National Conference for Earthquake Engineering (Bologna).

Bosiljkov, V., Bokan-Bosiljkov, V., Strah, B., Velkavrh, J., and Cotič, P. (2010). Review of innovative techniques for the knowledge of cultural assets (geometry, technologies, decay), PERPETUATE (EC-FP7 project), Deliverable D 62.

Bosiljkov, V., and Kržan, M. (2012). Results of laboratory and in-situ tests on masonry properties and tables with mechanical parameters to be adopted in numerical modelling. PERPETUATE (ECFP7 project), Deliverable D 15.

Bosiljkov, V. Z., Totoev, Y. Z., and Nichols, J. M. (2005). Shear modulus and stiffness of brickwork masonry: an experimental perspective. Struct. Eng. Mech. 20, 21-44. doi: 10.12989/sem.2005.20.1.021

C.N.R. (1993). "Assessment of the exposure and the seismic vulnerability of buildings: instructions for making out the 1st level form," in Seismic Risk of Public Buildings (Rome: National Research Council-National group for the Defence from Earthquake).

Caprili, S., Mangini, F., Paci, S., Salvatore, W., Bevilacqua, M. G., Karwacka, E., et al. (2017). A knowledge-based approach for the structural assessment of cultural heritage, a case study: La Sapienza Palace in Pisa. Bull. Earthquake Eng. 15, 4851-4886. doi: 10.1007/s10518-017-0158-y

Caprili, S., Mangini, F., and Salvatore, W. (2015). "Numerical modelling, analysis and retrofit of the historical masonry building" La Sapienza"', in COMPDYN 2015, 5th ECCOMAS Thematic Conference on Computational Methods in Structural Dynamics and Earthquake Engineering. Pisa: Institute of Structural Analysis and Antiseismic Research School of Civil Engineering National Technical University of Athens (NTUA), 772-787.

Casarin, F., and Modena, C. (2008). Seismic assessment of complex historical buildings: application to Reggio Emilia Cathedral, Italy. Int. J. Archit. Heritage 2, 304-327. doi: 10.1080/15583050802063659

Castellazzi, G., D’Altri, A. M., de Miranda, S., Chiozzi, A., and Tralli, A. (2018). Numerical insights on the seismic behavior of a non-isolated historical masonry tower. Bull. Earthquake Eng. 16, 933-961. doi: 10.1007/s10518-017-0231-6

Castori, G., Borri, A., De Maria, A., Corradi, M., and Sisti, R. (2017). Seismic vulnerability assessment of a monumental masonry building. Eng. Struct. 136, 454-465. doi: 10.1016/j.engstruct.2017.01.035

Cattari, S., Curti, E., Giovinazzi, S., Lagomarsino, S., Parodi, S., and Penna, A. (2004). "Un modello meccanico per l'analisi di vulnerabilitá del costruito in muratura a scala urbana," in 11th Conference "Lingegneria Sismica in Italia" (Genova).

Cattari, S., Degli Abbati, S., Ferretti, D., Lagomarsino, S., Ottonelli, D., and Tralli, A. (2014). Damage assessment of fortresses after the 2012 Emilia earthquake (Italy). Bull. Earthquake Eng. 12, 2333-2365. doi: 10.1007/s10518-013-9520-x

Cattari, S., Lagomarsino, S., Bosiljkov, V., and D'Ayala, D. (2015). Sensitivity analysis for setting up the investigation protocol and defining proper confidence factors for masonry buildings. Bull. Earthquake Eng. 13, 129-151. doi: $10.1007 /$ s10518-014-9648-3

CdM (2011). "Linee guida per la valutazione e la riduzione del rischio sismico del patrimonio culturale con riferimento alle Norme Tecniche per le costruzioni di cui al decreto del Ministero delle Infrastrutture e dei trasporti del 14 gennaio 2008," in Supplemento Ordinario Alla Gazzetta Ufficiale (Rome: Istituto Poligrafico e Zecca dello Stato).

Chellini, G., Nardini, L., Pucci, B., Salvatore, W., and Tognaccini, R. (2014). Evaluation of seismic vulnerability of Santa Maria del Mar in Barcelona by an integrated approach based on terrestrial laser scanner and finite element modeling. Int. J. Archit. Heritage 8, 795-819. doi: 10.1080/15583058.2012.747115

Circolare (2019). Istruzioni per l'applicazione dell'«Aggiornamento Delle "Norme Tecniche per le Costruzioni" di cui al Decreto Ministeriale 17 Gennaio 2018.

Clementi, F., Gazzani, V., Poiani, M., and Lenci, S. (2016). Assessment of seismic behaviour of heritage masonry buildings using numerical modelling. J. Build. Eng. 8, 29-47. doi: 10.1016/j.jobe.2016.09.005

D’Amato, M., Laterza, M., and Diaz Fuentes, D. (2018). Simplified seismic analyses of ancient churches in Matera's landscape. Int. J. Archit. Heritage 13, 1-20. doi: 10.1080/15583058.2018.1511000

D’Ayala, D., Carriero, A., Sabbadini, F., Fanciullacci, D., Ozelik, P., Akdogan, M., et al. (2008). "Seismic vulnerability and risk assessment of cultural heritage buildings in Istanbul, Turkey," in 14th World Conference of Earthquake Engineering (Beijing).
D’Ayala, D. and Speranza, E. (2002). “An Integrated Procedure for the Assessment of SeismicVulnerability of Historic Buildings," in Proceedings of the 12th European Conference on Earthquake Engineering (London), 561.

Degli Abbati, S., D’Altri, A. M., Ottonelli, D., Castellazzi, G., Cattari, S., de Miranda, S., and Lagomarsino, S. (2019). Seismic assessment of interacting structural units in complex historic masonry constructions by nonlinear static analyses. Comp. Struc. 213, 51-71. doi: 10.1016/j.compstruc.2018. 12.001

D. M. (2018). Norme Tecniche per le Costruzioni, ed M.d.I.e.d. Trasporti. (Rome).

Dolce, M., and Moroni, C. (2005). "La valutazione della Vulnerabilitá e del Rischio Sismico degli Edifici Pubblici mediante le procedure VC e VM," in Atti del Dipartimento di Strutture (Geotecnica: Geologia applicata all'ingegneria), 4.

DPC (2000). Manuale per la Compilazione Della Scheda di Primo Livello di Rilevamento Danno, Pronto Intervento e Agibilità per Edifici Ordinari Nell'emergenza Post- sismica. ed D.d.P. Civile (DPC).

Formisano, A., Chiumiento, G., Fabbrocino, F., and Landolfo, R. (2017). "Comparative seismic evaluation between numerical analysis and Italian guidelines on cultural heritage applied to the case study of a masonry building compound," in Proceedings of the AIP Conference (Rhodes).

Formisano, A., Mazzolani, F., Florio, G., and Landolfo, R. (2010). "A quick methodology for seismic vulnerability assessment of historical masonry aggregates," in Proceedings of the COST Action C26 Final Conference "Urban Habitat Constructions under Catastrophic Events" (Naples), 577-582.

Fortunato, G., Funari, M. F., and Lonetti, P. (2017). Survey and seismic vulnerability assessment of the Baptistery of San Giovanni in Tumba (Italy). J. Cult. Heritage 26, 64-78. doi: 10.1016/j.culher.2017.01.010

Fuentes, D. D., Laterza, M., and D'Amato, M. (2019) “Seismic vulnerability and risk assessment of historic constructions: the case of masonry and adobe churches in italy and chile," in Structural Analysis of Historical Constructions, Vol. 18 RILEM Bookseries, eds R. Aguilar, D. Torrealva, S. Moreira, M. A. Pando, and L. F. Ramos (Cham: Springer). doi: 10.1007/978-3-319-99441-3_122

GNDT-SSN (1994). Scheda di Esposizione e Vulnerabilità e di Rilevamento Danni di Primo Livello e Secondo Livello (Muratura e Cemento Armato), GNDT-SSN.

ICOMOS (2005). Recommendations for the Analysis, Conservation and Structural Restoration of Architectural Heritage. International scientific committee for analysis and restoration of structures and architectural heritage. ed ISCARSAH (Barcelona: ICOMOS).

Kržan, M., Gostič, S., Cattari, S., and Bosiljkov, V. (2015). Acquiring reference parameters of masonry for the structural performance analysis of historical buildings. Bull. Earthquake Eng. 13, 203-236. doi: 10.1007/s10518-014-9686-x

Lagomarsino, S. (2006). On the vulnerability assessment of monumental buildings. Bull. Earthquake Eng. 4, 445-463. doi: 10.1007/s10518-006-9025-y

Lagomarsino, S., and Cattari, S. (2015). PERPETUATE guidelines for seismic performance-based assessment of cultural heritage masonry structures. Bull. Earthquake Eng. 13, 13-47. doi: 10.1007/s10518-014-9674-1

Magalhães, A., and Veiga, R. (2009). Physical and mechanical characterisation of historic mortars. Application to the evaluation of the state of conservation. Mater. Const. 59, 61-77.

Mallardo, V., Malvezzi, R., Milani, E., and Milani, G. (2008). Seismic vulnerability of historical masonry buildings: a case study in Ferrara. Seismic Reliab. Anal. Prot. Historic Build. Heritage Sites 30, 2223-2241. doi: 10.1016/j.engstruct.2007.11.006

Mazzotti, C., Savoia, M., Chinni, C., and Perri, G. (2013). Una metodologia speditiva per la valutazione di vulnerabilitá sismica di edifici in muratura e calcestruzzo armato. Progettazione Sismica 4:2. doi: 10.7414/PS.4.2.95-112

Miano, A., Jalayer, F., Ebrahimian, H., and Prota, A. (2017). Cloud to IDA: efficient fragility assessment with limited scaling. Earthquake Eng. Struct. Dyn. 2017, 1-24. doi: 10.1002/eqe.3009

Milani, G. (2013). Lesson learned after the Emilia-Romagna, Italy, 20-29 May 2012 earthquakes: a limit analysis insight on three masonry churches. Eng. Fail. Anal. 34, 761-778. doi: 10.1016/j.engfailanal.2013.01.001

Oliveira, C. S. (2003). Seismic vulnerability of historical constructions: a contribution. Bull. Earthquake Eng. 1, 37-82. doi: 10.1023/A:1024805410454

Orduña, A., and Lourenço, P. B. (2001). "Limit analysis as a tool for the simplified assessment of ancient masonry structures," in Historical Constructions (Guimarães: University of Minho), 511-520. 
Ramírez, E., Lourenço, P. B., and D’Amato, M. (2019). "Seismic assessment of the matera cathedral," in Structural Analysis of Historical Constructions, Vol. 18 RILEM Bookseries, eds R. Aguilar, D. Torrealva, S. Moreira, M. A. Pando, and L. F. Ramos (Cham: Springer). doi: 10.1007/978-3-319-99441-3_144

Ramos, L. F., and Lourenço, P. B. (2004). Modeling and vulnerability of historical city centers in seismic areas: a case study in Lisbon. Eng. Struct. 26, 1295-1310. doi: 10.1016/j.engstruct.2004.04.008

Roca, P., Cervera, M., Gariup, G., and Pelá, L. (2010). Structural analysis of masonry historical constructions. Classical and advanced approaches. Arch. Comput. Methods Eng. 17, 299-325. doi: 10.1007/s11831-010-9046-1

Roca, P., and Elyamani, A. (2018). A review on the study of historical structures using integrated investigation activities for seismic safety assessment. Part II: model updating and seismic analysis. Sci. Cult. 4, 29-51. doi: 10.5281/zenodo.1048243

Rossi, M., Cattari, S., and Lagomarsino, S. (2015). Performance-based assessment of the Great Mosque of Algiers. Bull. Earthquake Eng. 13, 369-388. doi: 10.1007/s10518-014-9682-1

Salonia, P., Bellucci, V., Scolastico, S., Marcolongo, M., and Leti Messina, T. (2007). "3D survey technologies for reconstruction, analysis and diagnosis in the conservation process of cultural heritage," in Proceedings of CIPA, (Athens).

SISMA (2007). System Integrated for Security Management Activities in Cultural Heritage (2000-2006). ed c.i.I.I.B.C. 3B035 (Perugia: Petruzzi).
Vasconcelos, G., and Lourenço, P. (2009). Experimental characterization of stone masonry in shear and compression. Constr. Build. Mater. 23, 3337-3345. doi: 10.1016/j.conbuildmat.2009.06.045

Zuccaro, G., Albanese, V., Cacace, F., Mercuri, C., Papa, F., Pizza, A. G., et al. (2008). "Seismic vulnerability evaluations within the structural and functional survey activities of the COM bases In Italy," in AIP Conference Proceedings, 1665-1674. doi: 10.1063/1.2963797

Zuccaro, G., and Cacace, F. (2015). Seismic vulnerability assessment based on typological characteristics. The first level procedure "SAVE". Soil Dyn. Earthquake Eng. 69, 262-269. doi: 10.1016/j.soildyn.2014. 11.003

Conflict of Interest Statement: The authors declare that the research was conducted in the absence of any commercial or financial relationships that could be construed as a potential conflict of interest.

Copyright (c) 2019 Caprili and Puncello. This is an open-access article distributed under the terms of the Creative Commons Attribution License (CC BY). The use, distribution or reproduction in other forums is permitted, provided the original author(s) and the copyright owner(s) are credited and that the original publication in this journal is cited, in accordance with accepted academic practice. No use, distribution or reproduction is permitted which does not comply with these terms. 